\title{
Modeling sediment concentration and discharge variations in a small Ethiopian watershed with contributions from an unpaved road
}

\author{
Christian D. Guzman ${ }^{1}$, Seifu A. Tilahun ${ }^{2}$, Dessalegn C. Dagnew ${ }^{2}$, Assefa D. Zegeye ${ }^{1}$, Tigist Y. Tebebu ${ }^{1}$, \\ Birru Yitaferu ${ }^{3}$, Tammo S. Steenhuis ${ }^{1,2^{*}}$ \\ ${ }^{1}$ Department of Biological and Environmental Engineering, Cornell University, Ithaca, 206 Riley Robb Hall, NY 14853-5701, USA. \\ ${ }^{2}$ Faculty of Civil and Water Resources Engineering, Institute of Technology, Bahir Dar University, Bahir Dar, Ethiopia. \\ ${ }^{3}$ Amhara Regional Agriculture Research Institute, Bahir Dar, Ethiopia. \\ ${ }^{*}$ Corresponding author. Tel.: +1-607-255-2489. E-mail: tss1@cornell.edu
}

\begin{abstract}
Drainage of paved and unpaved roads has been implicated as a major contributor of overland flow and erosion in mountainous landscapes. Despite this, few watershed models include or have tested for the effect roads have on discharge and sediment loads. Though having a model is an important step, its proper application and attention to distinct landscape features is even more important. This study focuses on developing a module for drainage from a road and tests it on a nested watershed (Shanko Bahir) within a larger previously studied site (Debre Mawi) that receives overland flow contributions from a highly compacted layer of soil on an unpaved road surface. Shanko Bahir experiences a sub-humid monsoonal climate and was assessed for the rainy seasons of 2010, 2011, and 2012. The model chosen is the Parameter Efficient Distributed (PED) model, previously used where saturation-excess overland flow heavily influences discharge and sediment concentration variation, though infiltration-excess occasionally occurs. Since overland flow on unpaved surfaces emulates Hortonian flow, an adjustment to the PED model (the developed module) advances possible incorporation of both flow regimes. The modification resulted in similar modeling performance as previous studies in the Blue Nile Basin on a daily basis (NSE $=0.67$ for discharge and 0.71 for sediment concentrations). Furthermore, the road while occupying a small proportion of the sub-watershed (11\%) contributed importantly to the early discharge and sediment transport events demonstrating the effect of roads especially on sediment concentrations. Considerations for the dynamic erodibility of the road improved sediment concentration simulation further (NSE $=0.75$ ). The results show that this PED modeling framework can be adjusted to include unpaved compacted surfaces to give reasonable results, but more work is needed to account for contributions from gullies, which can cause high influxes of sediment.
\end{abstract}

Keywords: Saturation excess runoff; Infiltration excess (Hortonian) runoff; Soil erosion; Ethiopian highlands; PED model.

\section{INTRODUCTION}

\section{Unpaved road contributions in watersheds}

In sub-humid watersheds, the usual assumptions for most hydrological models may overlook specific flow regimes and complicate prediction efforts. Specifically, the most erosive flow events may result from the cumulative effect of long duration rainfall events rather than soil infiltration capacities (Bayabil et al., 2010; Tilahun et al., 2015, 2016). Additionally, relying on one runoff generation mechanism may complicate incorporation of contributions such as drainage of roads. While some modelers have relied on infiltration-excess, employing an SCS Curve Number approach (Arnold et al., 1998; Haith and Shoemaker, 1987; Krysanova et al., 1998; SCS, 1956; Williams et al., 1984), others use saturation-excess as the principal runoff generating mechanism in catchments (Beven and Kirkby, 1979; Bingner and Theurer, 2007; Buytaert et., 2004; Collick et al., 2009; Dunne and Black, 1970; Liu et al., 2008; Steenhuis et al., 2009). In Ethiopian mountainous basins, both mechanisms likely occur in different watersheds, at different extents, and at different times during a rainy season (Betrie et al., 2011; van Griensven et al., 2012; Tilahun et al., 2016). Selecting one mechanism or a combination thereof for modeling affects how conservation or urbanization plans are fulfilled, highlighting the importance of these hydrological considerations and their application.

Sediment contributions and hydrological impacts from roads have not been thoroughly addressed in Ethiopian watersheds. Nyssen et al. (2002) studied gully development associated with roads in Tigray, Ethiopia by investigating drainage areas, slope, and topographic thresholds similar to Anderson and MacDonald's (1998) work in the Caribbean simulating road erosion contributions. In the wetter, (sub) humid, Amhara region, more discussion is needed concerning the impact of new roads on hydrology. Montgomery (1994) states that road drainage strongly influences the erosional processes due to faster flow peaks and slightly higher total discharge, observed particularly in monsoonal climates (Ziegler and Giambelluca, 1997). Thus, the hydrologic response becomes more variable (Rhoads, 1995). Furthermore, an increase in a watershed's imperviousness correspondingly impacts soil water processes (Shuster et al., 2005). Dunne and Dietrich (1982) show that unpaved roads and footpaths in Kenya can provoke up to $50 \%$ of total erosion, while comprising only $2 \%$ of the catchment. These impacts are frequently observed in Ethiopia (Nyssen et al., 2002) but seldom analyzed or modeled with runoff data. These roads clearly contribute disproportionately and models should be modified to incorporate these distinct flow patterns.

Hence, the model structure highlighted by Steenhuis et al. (2013) was used for this investigation in a small sub-humid highland watershed to assess if road runoff contributions could be incorporated for improved results. The hypothesis is that the higher relative runoff and sediment generated in this subwatershed, compared to nearby sub-watersheds, is caused by excess flow coming from the unpaved road. Furthermore, adding varied land use types generating sediment was another motivation to work with this conceptual model. 


\section{Selecting a modeling approach for sub-humid highland hydrology and erosion}

In the Ethiopian highlands, modeling studies are numerous but their structures are usually deterministic, physically-based, and dominated by the Horton paradigm, with very few including the effect of drainage of rural roads. Some examples are, though not limited to, SWAT (Betrie et al., 2011; Mekonnen et al., 2009; Setegn et al., 2010; Tibebe and Bewket, 2011; Yesuf et al., 2015), SWAT-Water Balance (Easton et al., 2010; White et al., 2011), WATEM/SEDEM model (Haregeweyn et al., 2013), Limburg soil erosion model (Nyssen et al., 2006; Hengsdijk et al., 2006), and AGNPS (Mohammed et al., 2004). SWAT-WB was the only listed example of a saturation-excess, water balance type model. These approaches attempt explicit characterization of landscape heterogeneity to reproduce complexity, however, finding the underlying set of hydrological principles may better describe catchment hydrology (McDonnell et al., 2007; Savenije, 2010). Dooge (1986) explains that purely analytical or statistical mechanics will not provide the accurate basis for prediction in hydrology.

Most problems in catchment hydrology are systems of "organized complexity", states Dooge, which can be initially analyzed on the basis of small scale physics but encounter serious problems in parameter specification due to the spatial variability in catchments. Interestingly, there have been 50 years of Curve Number based modeling, a theory known to not work, continually used in practice uncritically with few field-based inquiries to oppose this conceptual view of the world (Burt and McDonnell, 2015). Pedo-transfer functions (Steenhuis et al., 2013) use a semi-physical interpretation of a watershed's storage capacity based on field observations to represent the fundamental runoff generation mechanisms. This simulates runoff once the soil becomes totally saturated and is unable to accept incoming rainfall (Kirkby and Chorley, 1967; Legates et al 2011) emphasizing the variable source area concept that determines storm runoff in humid climates (Dunne, 1978; Dunne and Black, 1970; Hewlett and Hibbert, 1967). Separation of infiltrating or saturated areas determines whether certain areas will accept incoming rainfall. Legates et al. (2011) argued that such frameworks are essential for understanding hydrology, sediment transport, and nutrient loss. Such approach used by Steenhuis et al. (2013), employed for this study, has been useful for previous researchers in these highlands (Tilahun et al., 2013a, b, 2015).

\section{A saturation-excess erosion model for unpaved road assessment}

The Parameter Efficient Distributed (PED) model (Tilahun et al., 2013a, b, 2015) is a simple semi-distributed model based on Steenhuis et al. $(2009,2013)$ capable of simulating stream discharges and sediment concentrations on a daily, weekly, and 10-day basis using saturation-excess overland flow patterns. For the upper Nile basin, Van Griensven et al. (2012) assert that modeling necessarily gives more attention to the dominating hydrological processes, though infiltration-excess and saturation-excess may be happening at the same place at different times of the season in the catchment and vice versa. The PED model emphasizes saturation-excess as the more likely runoff generation mechanism and assumes the presence of Hortonian runoff is limited, though still possible (Dunne, 1978).

In this study, the PED model is evaluated for a multi-land use sub-watershed (Shanko Bahir) within a previously studied Ethiopian highland watershed (Debre Mawi) and a simple modification is proposed. The dominant runoff mechanism is considered to be saturation-excess based on experimental data (Tilahun et al., 2015), however the study aims to integrate the overland flow on unpaved surfaces as a complementary runoff and sediment contributor. Shanko Bahir was monitored during the three rain seasons (wet period) in each of the respective years 2010, 2011, and 2012 since runoff is only generated during these times in its ephemeral streams. Tilahun et al. (2015) recently modeled the hydrological and erosion patterns for the total surrounding watershed area of Debre Mawi and other nearby sub-watersheds. The Shanko Bahir sub-watershed, however, had to be modeled separately as this investigation demonstrates due to flow contributions from a road that borders and intersects the Debre Mawi watershed. The unpaved road surface, while causing difficulties for the PED as previously developed, provides an opportunity to consider multiple complementary flow contributing mechanisms during larger storms early in the rainy season. Thus, the objective of this study was to develop a module that would account for the added discharge and sediment contributions from an unpaved road surface. The module in this study was incorporated as a component of the PED model and its performance was evaluated to examine if its application accounted for the hydrological and geomorphological trends. The tested module can also be added in other models that are used in the Ethiopian highlands.

\section{MATERIAL AND METHODS}

\section{Study site}

The Debre Mawi watershed in the Blue Nile Basin of the Ethiopian Highlands, is located $30 \mathrm{~km}$ south of Bahir Dar (Figure 1, 2). The sub-humid climate patterns, clay soils, and agricultural cultivation patterns, described below, are similar to the nearby watersheds surrounding the Adet station of the Amhara Regional Agricultural Research Institute (ARARI) which has a long-standing presence researching hydrology and erosion in this strategic teff (Eragrostis tef) growing area of the Amhara region. The catchments experience a warm, sub-humid, semimonsoonal climate with a unimodal rainfall pattern and an average of $1,100 \mathrm{~mm}$ of rainfall, $80 \%$ of which falls in this location from the months of June to September (Mekonnen and Melesse, 2011; Teshome et al., 2013; Tilahun et al., 2015). Due to its elevation of between 2,200 to 2,300 $\mathrm{m}$ a.s.l. it is classified in the Weyna Dega agro-ecological belt (Hurni, 1998). The main outlet for the 95 ha portion of the Debre Mawi watershed, studied by Tilahun et al. $(2015,2016)$, was denoted as "Weir 5" and is jointly monitored by Bahir Dar University and ARARI. The 14 ha Shanko Bahir sub-watershed is named after the village within it and corresponds to one of the four gauged subwatersheds of the 95 ha northern portion, referred to as "the sub-watershed at Weir 2" in the previous investigation (Tilahun et al., 2015). The nearest sub-watershed to Shanko Bahir in that study was adjacently located just to the west, represented by "Weir 1" (Figure 1) (Tilahun et al., 2015, 2016), and was used for model parameter fitting and comparison. For more information on the gauging of the larger encompassing watershed and surrounding sub-watersheds refer to Tilahun et al. (2015, 2016).

The soils, studied through geological pit profiles, are characterized by an A horizon composed of shallow nitisols in the top portion of the watershed and deep vertisols in the bottom portion of the watershed (Abiy, 2009). Nitisols in the upper reaches are well drained, red, tropical soils with at least $30 \%$ clay and an angular block structure. Vertic nitisols are located throughout the midslope area. In the bottomlands, the Vertisols 

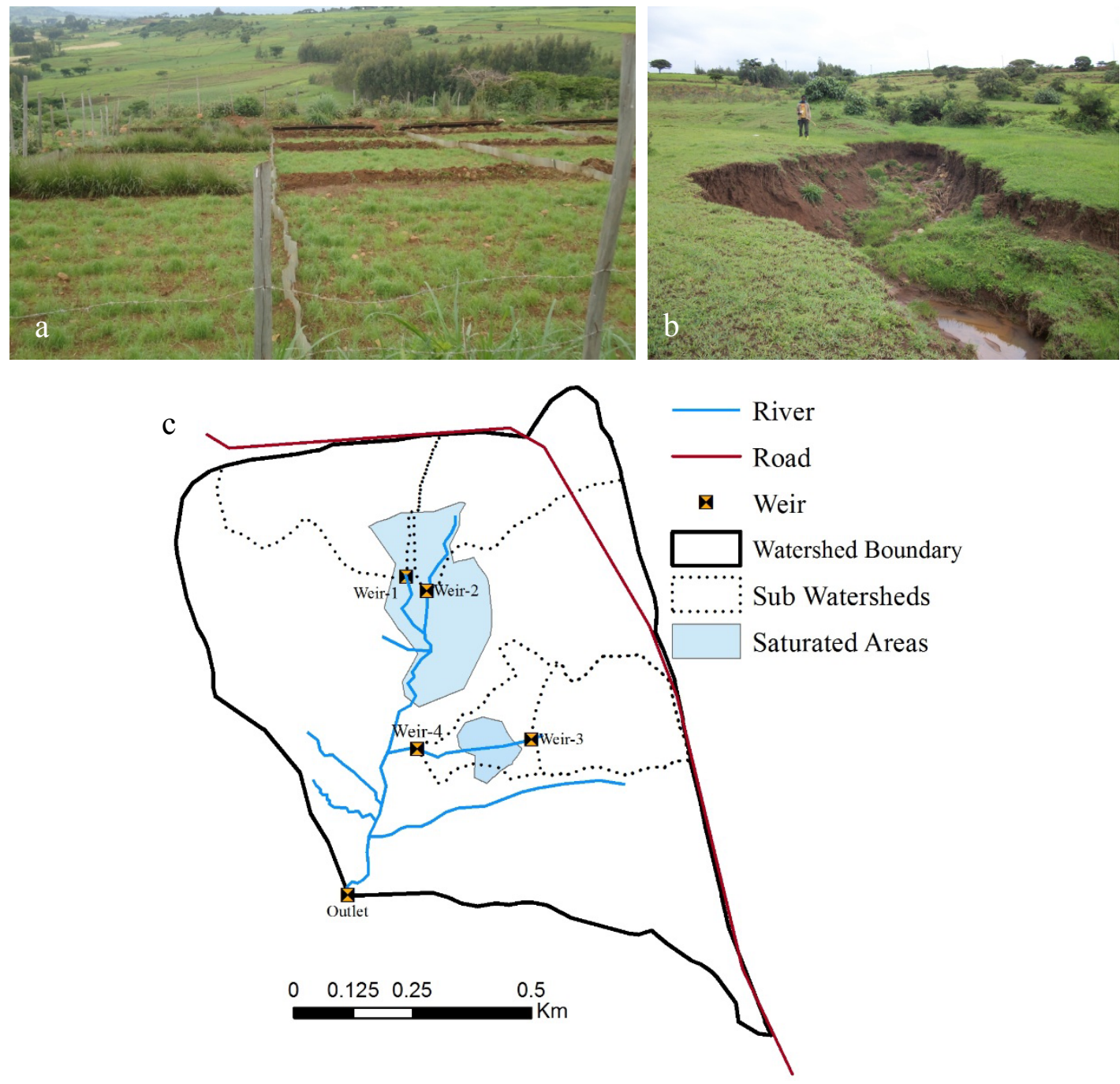

Fig. 1. The 95 ha Debre Mawi watershed previously studied in Tilahun et al. (2015), demonstrating (a) the land use, (b) gully in the bottom saturated area, and (c) the larger area with each of the sub-watersheds studied (Weir 1, Weir 2, Weir 3, Weir 4) (Figure from Tilahun et al., 2016).

have a high percentage of clay content (above 70\%) and are characterized as having a dark brown to black color with a strong shrink-swell activity (ISRIC, 2014). This is similar for the two sub-watersheds (Weir 1 and Shanko Bahir) and the main watershed since the landscape converges to a central waterway beginning in the north near the first two weirs and continuing on to the outlet weir.

A variety of cereals are cultivated in the watershed including maize (Zea mays), barley (Hordeum vulgare L.), wheat (Triticum sp.), finger millet (Eleusine coracana), and teff (Eragrostis tef). Several legumes are also intercropped or cultivated on fields after harvest as a second season crop such as haricot beans (Phaseolus vulgaris) and lupine (Lupinus albus L.). Finally, potatoes (Solanum tuberosum L.) can be cultivated throughout the season to provide early and later sources of household income and food. Aside from cultivated areas, the watershed is composed of fallow lands, grazing areas, and eucalyptus plantations. Other areas consist of native bushland or trees that have remained in place for household use or have grown in on unused areas on rough or steep terrain. The general soil characteristics and cropping systems of the Debre Mawi watershed, the sub-watershed at Weir 1, and the Shank Bahir sub-watershed are similar, though with some unique differ- ences. The sub-watershed at Weir 1 has relatively deep vertic nitisol soils and had a greater portion of land dedicated to grassland. Shanko Bahir had a majority of its area dedicated to crops and eucalyptus plantations with a gully at the saturated bottom area (Figure 1).

The unpaved road which connects Bahir Dar to Addis Ababa via Adet consists of a compacted soil and gravel road of about $10 \mathrm{~m}$ in width with another 2 to $4 \mathrm{~m}$ on each side of the road to accommodate grassed drainage ditches. The road heading south from Bahir Dar borders the northern and eastern border of the Debre Mawi watershed before continuing on to the city of Adet. Every year, the surface has a new layer of gravel and soil added that is compacted before the rainy season begins. Since it intersects Shanko Bahir, some of the flow from the northern portion (Figure 2a) will not always be received as overland flow at the weir outlet as it is intercepted by the northernmost roadside drainage ditch and diverted to another watershed. For longer events, however, these ditches overflow and since the northernmost outside edge is super-elevated above the centerline of the road (Figure 3), the overland flow from the northern portion of the sub-watershed will continue down to the weir as runoff. 


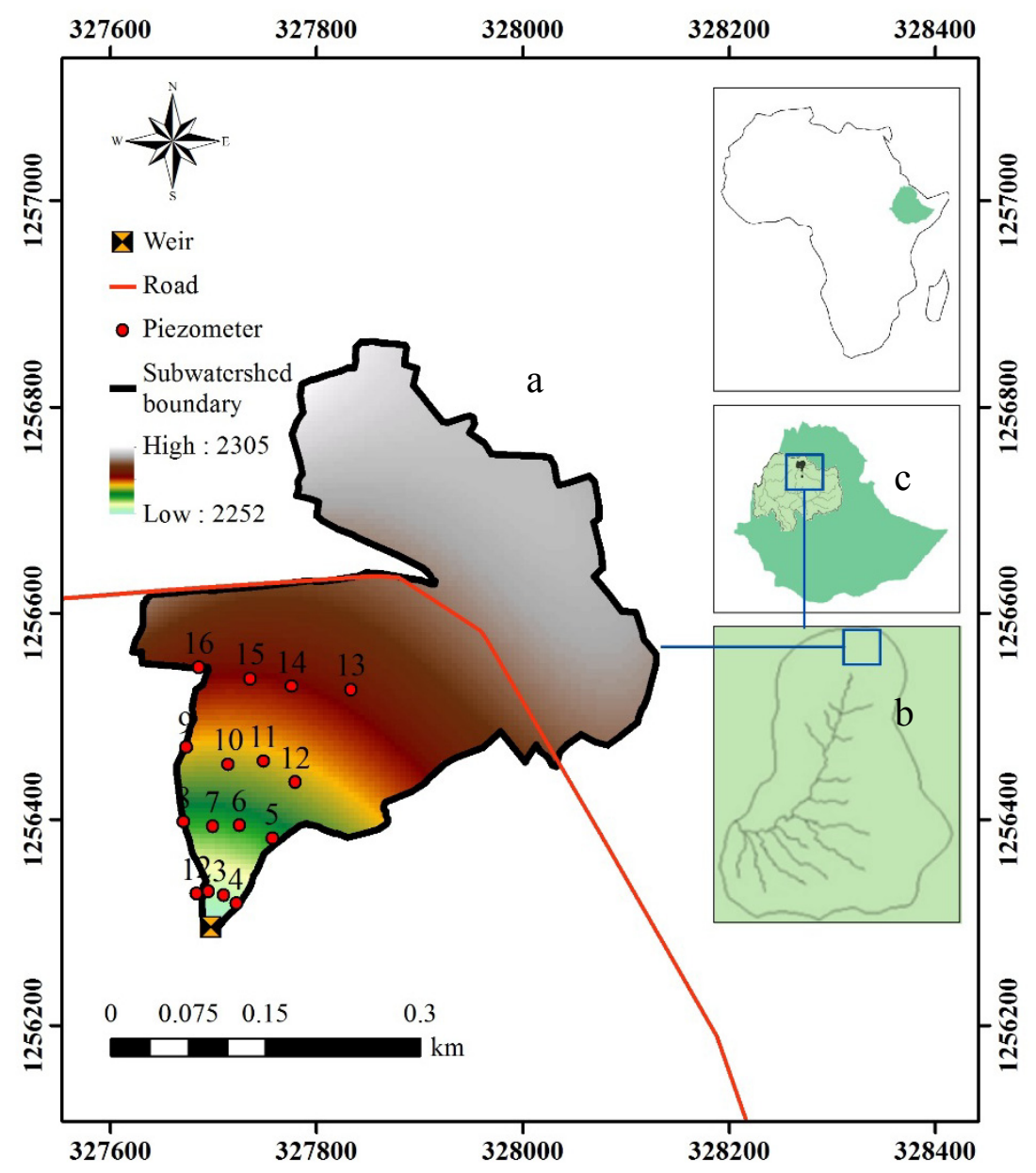

Fig. 2. The 14-ha study basin (Shanko Bahir) in the northern portion of (b) the Debre Mawi watershed (523 ha) (Tilahun et al., 2015) in (c) the Blue Nile Basin (17.4 Mha). The red line in Figure 2a indicates the compacted unpaved road and the numbered red dots indicate piezometer monitoring wells.
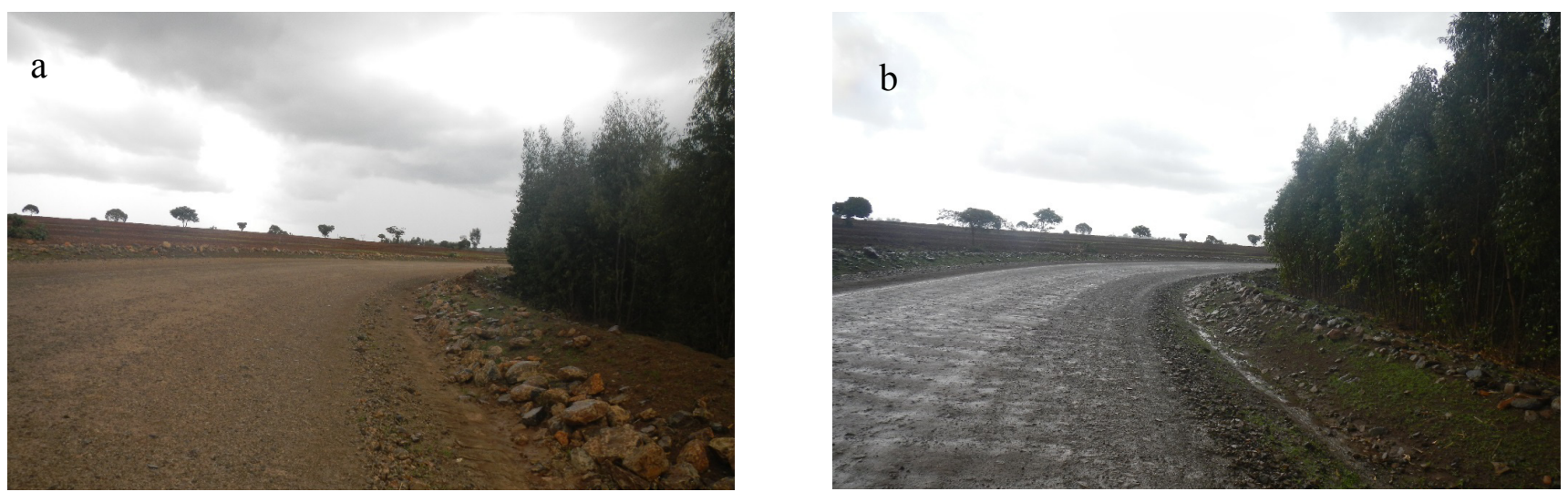

Fig. 3. Unpaved road at super-elevated curve in the northern part of the sub-watershed during (a) dry and (b) rainy conditions.

\section{Hydrometric and sediment concentration data}

Rainfall was measured continuously at 5 -min intervals by a WatchDog automatic tipping bucket rain gauge $(0.25 \mathrm{~mm}$ resolution, Spectrum Technologies, Inc. Aurora, Illinois, USA) during each rainy season and complemented by data collected at the weather station in the Adet Research Center of ARARI. Daily evaporation data was also provided by ARARI. Stream discharge data were recorded by paid community assistants who documented stage and velocity measurements at a rectangular broad-crested weir established in 2010 by one of the co- authors (Tilahun et al., 2015). Measurements were taken at 10min intervals starting at the onset of a rainstorm and continued until the streamflow returned to pre-storm levels or declined to below $1 \mathrm{~cm}$. Flow rate was calculated by converting the stage to discharge using a stage-discharge relationship (Tilahun et al., 2015). Total daily discharge was calculated by the summation of all storm stream flow data within a 24-hour period.

Measured sediment concentrations were assumed to be constant during the 10-min period. Each 10-min interval sediment concentration value was estimated by collecting a 1-L grab sample of storm water and filtering using a $2.5 \mu \mathrm{m}$ Whatman 


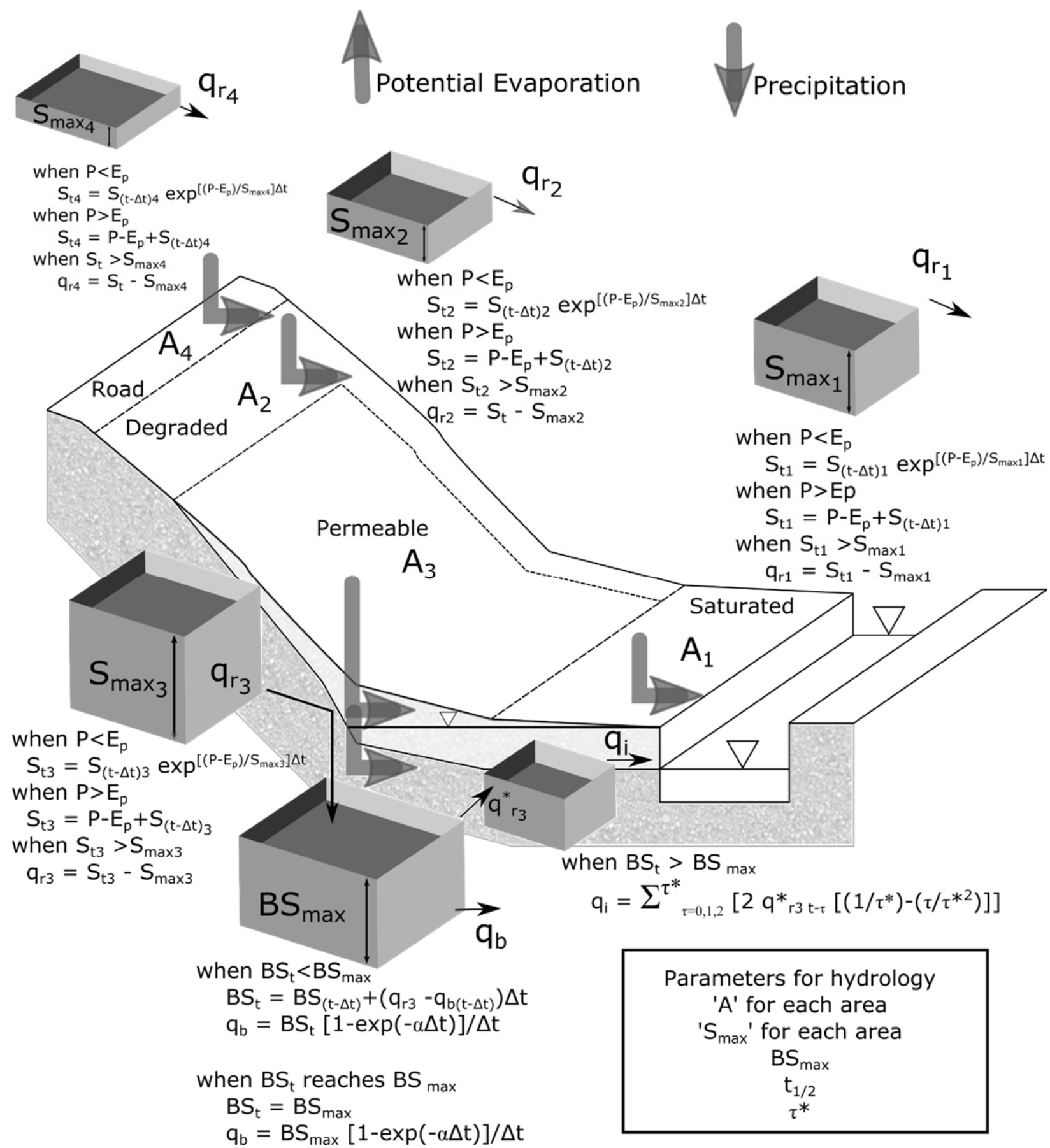

Fig. 4. Diagram of the model structure for the hydrology sub-model of the Parameter Efficient Distributed model. $A$ denotes the area fraction for the different areas in the watershed: (1) saturated, (2) degraded, (3) permeable, and (4) road surfaces. $S_{\max }$ is the maximum water storage capacity of these areas; $B S_{\max }$ is the maximum baseflow storage for the linear reservoir, $t_{1 / 2}(=0.69 / \alpha)$ is the time in days required to reduce the baseflow volume by a factor of 2 under no recharge, and $\tau^{*}$ is the duration of the time for interflow to cease after a single storm event (based on Tilahun et al., 2013b). $q_{r 3}{ }^{*}-\tau$ is the percolation produced on $t-\tau$ days as derived by Steenhuis et al. (2009).

filter paper. The retained soil mass was determined by weighing the sample after oven drying for 24 hours at $105^{\circ} \mathrm{C}$. Sediment loads for a storm period and daily interval were calculated by multiplying the flow rate and the sediment concentration during each interval and then summing the total during each interval. Daily sediment concentration values were calculated by dividing the daily sediment load by the daily streamflow discharge volume.

\section{The PED model overview}

The PED model is a combined semi-distributed conceptual water balance model (Steenhuis et al., 2009) and sediment model (Tilahun et al., 2013b). The model is described in this section and modifications for unpaved road contributions are explained in the next section. 
While the model was based on field observations and experimental data showing higher soil infiltration capacities than storm intensities in Ethiopia (Bayabil et al., 2010; Tebebu et al., 2010), its formulation has origins in hydrological and sediment detachment processes observed both inside and outside of Ethiopia (Steenhuis et al., 2013). The water balance component is based on the Thornthwaite and Mather (1955) procedure for predicting watershed outflow in the eastern U.S., and has been used for predicting recharge in New York State (Steenhuis and Van der Molen, 1986), while the sediment transport portion follows a theoretical framework involving studies from SouthEast Asia and Australia (Ciesiolka et al., 1995). Furthermore, its hydrological framework has been applied for streamflow and lake levels in Central America (Caballero et al., 2013) and in the Caribbean (Steenhuis et al., 2013), respectively.

The hydrology sub-model of the PED model (Figure 4) was developed for the Ethiopian highlands (Steenhuis et al., 2009; Collick et al., 2009) and employs a Thornthwaite-Mather (TM) procedure to predict recharge and runoff through three distinct portion of the watershed that either infiltrate and contribute to baseflow or produce runoff directly (Steenhuis and Van der Molen, 1986).

$$
S_{t_{j}}=S_{(t-\Delta t)_{j}}+\left(P-E_{a}-q_{r_{j}}\right) \Delta t
$$

The daily TM type water balance is calculated for the soil moisture storage $\left(S_{t_{j}}\right)$ in each of the three areas (saturated $j=1$, degraded $j=2$, permeable $j=3$ ) leading to the drawing down or exceeding (producing outflow, $q_{r_{j}}$ ) of the storage

(Thornthwaite and Mather, 1955; Steenhuis and Van der Molen, 1986; Steenhuis et al., 2009), using daily precipitation $(P)$ and potential evaporation $\left(E_{p}\right)$ as inputs. $E_{a}$ is the actual evaporation and is equal to potential evaporation $\left(E_{p}\right)$ during wet periods and conversely linearly related to potential evaporation when evaporation exceeds rainfall through the TM procedure (Steenhuis and Van der Molen, 1986).

When $P<E_{p}$, and $S_{t j}<S_{\max j}$, where $S_{\max }$ is the maximum water storage capacity parameter for each of the three areas $\left(S_{\max 1}, S_{\max 2}, S_{\max 3}\right)$, then soil moisture is drawn down by:

$$
S_{t_{j}}=S_{(t-\Delta t)_{j}}\left[\exp \left(\frac{\left(P-E_{p}\right) \Delta t}{S_{\text {max }_{j}}}\right)\right]
$$
is:

When $P>E_{p}$, and $S_{t j}<S_{\max j}$ then the available water storage

$$
S_{t_{j}}=S_{(t-\Delta t)_{j}}+\left(P-E_{p}\right) \Delta t
$$

Finally, when $P>E_{p}$, and $S_{t j}>S_{\max j}$ then runoff from each generating area $\left(q_{r 1,2}\right)$ and percolation $\left(q_{r 3}\right)$ are calculated by:

$$
q_{r_{j}}=S_{t_{j}}-S_{\text {max }_{j}} \quad j=1,2,3
$$

For the percolation $\left(q_{r 3}\right)$ which flows through the subsoil, the water becomes recharge for two reservoirs that produce baseflow or interflow (filling the baseflow reservoir first):

$$
B S_{t}=B S_{(t-\Delta t)}+\left(q_{r_{3}}-q_{b(t-\Delta t)}\right) \Delta t
$$

$q_{b, t}=\frac{B S_{t}[1-\exp (-\alpha \Delta t)]}{\Delta t}$

The first reservoir is called the baseflow storage $\left(B S_{t}\right)$, representing the linear aquifer. When $B S_{t}<B S_{\max }$ then the outflow $\left(q_{b}\right)$ is calculated through the two equations (Eq. 5, 6). The value for $\alpha$ is found through the value given to the parameter $t_{1 / 2}$ $(=0.69 / \alpha)$ for the half-life of the aquifer. When the maximum storage is reached then the $B S_{t}$ is replaced with $B S_{\max }$ in Eq. (6) and the interflow at time $(t), q_{i, t}$ can be calculated by the superimposition of the fluxes from previous individual events:

$q_{i, t}=\sum_{\tau=0,1,2}^{\tau^{*}} 2\left(q_{r_{3}}{ }^{*} t-\tau\right)\left(\frac{1}{\tau^{*}}-\frac{\tau}{\tau^{* 2}}\right), \tau \leq \tau^{*}$

where $\tau$ are the days after a storm event occurs and $\tau^{*}$ is the duration of time after which the interflow produced by a single storm event ceases, and $q_{r 3}{ }_{t-\tau}$ is the percolation produced on $t-\tau$ days as derived by Steenhuis et al. (2009). Thus, the three distinct regions of the watershed are: (1) the saturated or (2) degraded areas producing runoff ( $q_{r 1}$ and $q_{r 2}$, respectively), and (3) the permeable areas which allow rainwater to infiltrate (becoming percolation, $q_{r 3}$ ) either flowing vertically to recharge the groundwater, and eventually baseflow $\left(q_{b}\right)$ or laterally as interflow $\left(q_{i}\right)$. These areas are represented fractionally in the nine-parameter hydrology model as $A_{1}, A_{2}, A_{3}$, with the subscripts for each region. The remaining six hydrology parameters are the corresponding maximum water storage capacity parameters $\left(S_{\max 1}, S_{\max 2}, S_{\max 3}\right), B S_{\max }$ which is the maximum groundwater storage, $\tau^{*}$ which is the duration of the period after the rainstorm until the interflow ceases (or residence time), and $t_{1 / 2}$ which is the half-life of the aquifer.

The sediment transport sub-model was developed by Tilahun et al. $(2013 b, 2015)$ and is based on a simplification of the velocity to sediment concentration relationship explained by $\mathrm{Yu}$ et al. (1997) and Ciesiolka et al. (1995), who adapted the original theory put forth by Hairsine and Rose (1992). Relating sediment concentrations at the source limit $\left(C_{s}, \mathrm{~kg} \mathrm{~m}^{-3}\right)$ to discharge the following relationship was found:

$C_{s_{j}}=a_{s_{j}} q_{r_{j}}{ }^{n}$

where $a_{s j}$ is a sediment transport coefficient for each area $(j=$ $1,2)$ and $n$ is an exponent set to 0.4 . Because of the changing nature of sediment transport in these region, two sediment transport parameters are used in place of the sediment transport coefficient (in Eq. 8) to represent two boundary conditions for each runoff producing area when calculating the sediment concentration transported $\left(C_{t}\right)$

$$
C_{t j}=\left[a_{S j}+H\left(a_{t j}-a_{s j}\right)\right] q_{r j}{ }^{n}
$$

The source limiting conditions $\left(a_{s}\right)$ denotes the conditions when entrainment of soil from the source area is limiting and the transport limiting conditions $\left(a_{t}\right)$ is for the sediment concentration in the water when there is equilibrium between deposition and entrainment of sediment. In total that makes four calibrated sediment transport parameters $\left(a_{s 1}, a_{s 2}, a_{t 1}, a_{t 2}\right)$.

The active rill variable $H$ shifts to simulate the movement between these two limiting conditions. The $H$ variable repre- 
sents the fractional area in the watershed with active rills forming on the soil surface and proportionally decreases as the rill network develops and become stable. For this analysis, during a brief period at the very beginning of each season the $H$ variable was set to 0.7 since not all the fields had been plowed and ready for cultivation (some crops such as teff require plowing later into the season) and then was set to 1 and decreased progressively to 0 . From Tilahun et al. (2013a, b), any sediment load contributions per unit watershed area $\left(Y, \mathrm{~kg} \mathrm{~m}^{-2} \mathrm{~d}^{-1}\right)$ would then be obtained by multiplying the concentration in Eq. (8) or (9) by the relative area and flux per unit area:

$$
\begin{aligned}
& Y_{j}=A_{j} q_{r_{j}}\left\{a_{s j} q_{r_{j}}{ }^{n}\right\} \\
& Y_{j}=A_{j} q_{r_{j}}\left\{\left[a_{s j}+H\left(a_{t_{j}}-a_{s_{j}}\right)\right] q_{r_{j}}{ }^{n}\right\}
\end{aligned}
$$

Using the four parameters for the erosion component with the nine parameters for the hydrology component, the daily average sediment concentration is calculated as (average daily sediment load divided by the daily proportional flux per unit area):

$$
C=\frac{\left(A_{1} q_{r_{1}}^{1.4}\left[a_{s 1}+H\left(a_{t 1}-a_{s 1}\right)\right]+A_{2} q_{r_{2}}^{1.4}\left[a_{s 2}+H\left(a_{t 2}-a_{s 2}\right)\right]\right)}{A_{1} q_{r_{1}}+A_{2} q_{r_{2}}+A_{3}\left(q_{i}+q_{b}\right)}
$$

where $C$ is suspended sediment concentration (in $\mathrm{kg} \mathrm{m}^{-3}$ ) and all runoff rates expressed in depth units, $\mathrm{mm} \mathrm{d}^{-1}$.

\section{Integrating road flow contributions to a saturation-excess erosion model}

Unpaved road surfaces have a very low hydraulic conductivity and therefore usually exhibit Hortonian overland flow necessitating a modified equation for sediment concentrations

$$
C=\frac{\left(A_{1} q_{r_{1}}{ }^{1.4}\left[a_{s_{1}}+H\left(a_{t_{1}}-a_{s_{1}}\right)\right]+A_{2} q_{r_{2}}{ }^{1.4}\left[a_{s_{2}}+H\left(a_{t_{2}}-a_{s_{2}}\right)\right]+A_{4} q_{r_{4}}{ }^{1.4}\left[a_{s_{4}}\right]\right)}{A_{1} q_{r_{1}}+A_{2} q_{r_{2}}+A_{3}\left(q_{b}+q_{i}\right)+A_{4} q_{r_{4}}}
$$

To add flow contributions to this model, another fractional area to account for the road surface $\left(A_{4}\right)$ is included. Also, the maximum water storage capacity parameter for the road $\left(S_{\max 4}\right)$ is required which will be much smaller in comparison to the other areas. Finally, a flow component $\left(q_{r 4}\right)$ that represents the overland flow contributed by the road is used to route the flow through the sub-watershed (Figure 4). The numerator for the sediment concentration equation (Eq. 11) is modified by adding the sediment load component Eq. (10a) contributed from the unpaved road surface. This will consist of the aforementioned areal fraction parameter $\left(A_{4}\right)$, flow component $\left(q_{r 4}\right)$, and a source limiting condition parameter $\left(a_{s 4}\right)$ to indicate that the sediment contributions are limited by what is available on the road surface. To consider the scenario where the road contributes sediment differently with the progression of the rainy season, sediment concentration is:

$$
C=\frac{\left(A_{1} q_{r_{1}}^{1.4}\left[a_{s_{1}}+H\left(a_{t_{1}}-a_{s_{1}}\right)\right]+A_{2} q_{r_{2}}^{1.4}\left[a_{s_{2}}+H\left(a_{t_{2}}-a_{s_{2}}\right)\right]+A_{4} q_{r_{4}}^{1.4}\left[a_{s_{4}}+H\left(a_{t_{4}}-a_{s_{4}}\right)\right]\right)}{A_{1} q_{r_{1}}+A_{2} q_{r_{2}}+A_{3}\left(q_{b}+q_{i}\right)+A_{4} q_{r_{4}}}
$$

where an additional parameter for transport limiting conditions $\left(a_{t 4}\right)$ will be included that denotes higher sediment transport at the beginning of the season and decreases to the source limiting conditions $\left(a_{s 4}\right)$ through the $H$ variable. This scenario will be referred to as the "dynamic erodibility" (Ziegler et al., 2000) of the road surface. The denominator is modified by adding the relative area $\left(A_{4}\right)$ and flux per unit area $\left(q_{r 4}\right)$ and Eq. (12) and (13) now show the saturation-excess erosion model with flow and sediment contributions from a road.

One further change is that for the road the input is the directly measured precipitation rather than the effective precipitation ( $P_{e}$, precipitation less evaporation) to model the direct response a road would have in achieving flow rather than storing precipitation. The initial abstractions are still taken into account through the superficial storage that is included in the model as the storage capacity factor for the road $\left(S_{\max 4}\right)$.

The main framework of the PED model remains intact with the adjustment made, however the new component provides an entry point for integration of the overland flow from unpaved surfaces and saturation-excess overland flow in a simple semidistributed model. While following the similar structure and mechanism for flow, the road contribution is mainly an exten- sion of the conceptual degraded area with a much smaller maximum water storage capacity that fills up quickly and produces runoff.

\section{Model calibration and evaluation}

Manual calibration procedure is employed to estimate bestfit parameters for each proportional areas $\left(A_{j}\right)$ and maximum water storage capacity $\left(S_{\max j}\right)$ so that the model closely simulates the runoff and sediment concentrations. The range of variability of the model parameters is based on the physical interpretations of their representation as well as their expected similarity to previously calibrated parameters for nearby subhumid watersheds (Tilahun et al., 2013, 2015). To start calibration, a first approximation of these parameter values were assigned based on the nearest sub-watershed (Weir 1, Tilahun et al., 2015) for the data collected in 2010 and 2011. The most sensitive parameters are the areal fraction of the saturated and degraded areas as well as the new areal fraction for road surface area. The $B S_{\max }$ parameter is the next most sensitive parameter for the remaining parameters. 
Criteria used to assess the ability of the models to predict discharge and sediment concentrations on a daily basis included a visual comparison between the modeled and observed hydrographs, Nash-Sutcliffe model efficiencies (NSE) (Nash and Sutcliffe, 1970), coefficient of determination $\left(R^{2}\right)$, root mean square error (RMSE), and percent bias (PBIAS) for validation in year 2012.

\section{RESULTS}

Previously, this sub-watershed had not been included in modeling studies due to receiving an unknown amount of runoff from road drainage ditches (Tilahun et al., 2015). Here, the analysis estimated that around $11 \%$ of the flow came from these road overland flow contributions. The predicted values for the PED road contribution with dynamic erodibility are reasonably close to measured values with a Nash Sutcliffe Efficiency (NSE) (Nash and Sutcliffe, 1970) coefficient of 0.72 for calibration of daily prediction of discharge (Table 1, Figure 5) and a NSE coefficient of 0.56 for calibration of the sediment concentrations (NSE $=0.73$ when excluding an extreme event on August 2, 2010; Table 2, Figure 7). Including the extreme event, the NSE values are lower for all the scenarios in calibration, however, it was important to include to account for the extreme variability in the sub-watershed. Evidence shows, however, that it is an uncharacteristically high peak most likely caused by processes other than overland flow. Detailed explanations for reasonable option to exclude this event are provided in the following sections. For validation, initial performance of this adjustment to the PED model is reassuring (NSE $>0.5$,PBIAS $\pm 30 \%$; Moriasi et al., 2007) and suggests that the road contributes an important portion of flow and sediment that can now be incorporated to erosion pattern studies in Debre Mawi.

\section{Hydro-sedimentological behavior of the Shanko Bahir catchment}

Temporal streamflow, sediment concentration, and sediment yield trends are important in determining the intensity and contribution of erosion processes throughout the season. The average discharge steadily increases in the ephemeral stream from June or late May until around September when the rainy season ends with an annual mean of $6.6 \mathrm{~mm} \mathrm{day}^{-1}$ for the storms measured (maximum of $34.4 \mathrm{~mm} \mathrm{day}^{-1}$ ). Storms in the first third of the season had on average a discharge of $7 \mathrm{~mm}$ day $^{-1}$, while in the second-third the average storm discharge was $8.5 \mathrm{~mm} \mathrm{day}^{-1}$, and $4.5 \mathrm{~mm} \mathrm{day}^{-1}$ in the final third. Figure $\mathrm{S} 1$ in the supplementary materials shows the discharge dynamics on the 10 -min time scale, illustrating the response to rainfall. The majority of sediment transported each rainy season tended to occur in the first half of the rainy season (an average of $7.4 \mathrm{t} \mathrm{ha}^{-1}$ compared to $2.1 \mathrm{t} \mathrm{ha}^{-1}$ ). The daily average sediment concentration was $5.1 \mathrm{~kg} \mathrm{~m}^{-3}\left(8.4 \mathrm{~kg} \mathrm{~m}^{-3}\right.$ average in the first half and $1.8 \mathrm{~kg} \mathrm{~m}^{-3}$ in the second half). The median daily sediment concentration was $2.7 \mathrm{~kg} \mathrm{~m}^{-3}$ and the first and third quartiles for daily sediment concentrations were $1.6 \mathrm{~kg} \mathrm{~m}^{-3}$ and $8 \mathrm{~kg} \mathrm{~m}^{-3}$, respectively with a maximum of $30.8 \mathrm{~kg} \mathrm{~m}^{-3}$.

Table 1. Parameter values optimized in the hydrology and sediment transport portions of the model for the sub-watershed at Weir 1 and the Shanko Bahir sub-watershed (at Weir 2) in the Debre Mawi watershed as well as for the scenarios with road area contributions (w. road) and dynamic erodibility of the road area (w. road d.e.). $A_{1}$ is the saturated area, $A_{2}$ is the degraded area and $A_{3}$ is the permeable hillslope area. $S_{\max }$ is the maximum water storage capacity in each area, $B S_{\max }$ is the maximum groundwater storage, $\tau^{*}$ is the duration of the interflow and $t_{1 / 2}$ is the half-life of the aquifer. Sediment transport coefficients are provided for the boundary conditions (transport limit $a_{t}$ and source limit $a_{s}$ ) for the saturated, degraded, and road areas. Values for Weir 1 are provided for comparison with Tilahun et al. (2015).

\begin{tabular}{|c|c|c|c|c|c|c|}
\hline Model Component & Parameter & Unit & Weir 1 & Weir 2 & $\begin{array}{c}\text { Weir } 2 \mathrm{w} . \\
\text { road }\end{array}$ & $\begin{array}{l}\text { Weir } 2 \text { w. } \\
\text { road d.e. }\end{array}$ \\
\hline \multirow[t]{13}{*}{ Hydrology } & Area & ha & 8.8 & 13.9 & 13.9 & 13.9 \\
\hline & Saturated area $A_{1}$ & $\%$ & 8 & 15 & 15 & 15 \\
\hline & $S_{\max }$ in $A_{1}$ & $\mathrm{~mm}$ & 80 & 80 & 80 & 80 \\
\hline & Degraded area $A_{2}$ & $\%$ & 20 & 27 & 15 & 15 \\
\hline & $S_{\max }$ in $A_{2}$ & $\mathrm{~mm}$ & 30 & 30 & 30 & 30 \\
\hline & Perm. area $A_{3}$ & $\%$ & 40 & 22 & 22 & 22 \\
\hline & $S_{\max }$ in $A_{3}$ & $\mathrm{~mm}$ & 60 & 60 & 60 & 60 \\
\hline & Road area $A_{4}$ & $\%$ & - & - & 11 & 11 \\
\hline & $S_{\max }$ in $A_{4}$ & $\mathrm{~mm}$ & - & - & 2 & 2 \\
\hline & $B S_{\max }$ & $\mathrm{mm}$ & 80 & 60 & 60 & 60 \\
\hline & $t_{1 / 2}$ & days & 70 & 70 & 70 & 70 \\
\hline & $\tau^{*}$ & days & 5 & 5 & 5 & 5 \\
\hline & Total area $\%$ & $\%$ & 68 & 64 & 63 & 63 \\
\hline \multirow[t]{8}{*}{ Sediment transport } & & & \multicolumn{4}{|c|}{ Transport limit } \\
\hline & Saturated area $a_{t 1}$ & $\left(\mathrm{~kg} \mathrm{~m}^{-3}\right)\left(\mathrm{mm} \mathrm{day}^{-1}\right)^{-0.4}$ & 1 & 1 & 1 & 1 \\
\hline & Degraded area $a_{t 2}$ & $\left(\mathrm{~kg} \mathrm{~m}^{-3}\right)\left(\mathrm{mm} \text { day }^{-1}\right)^{-0.4}$ & 6 & 5 & 5 & 5 \\
\hline & Road area $a_{t 4}$ & $\left(\mathrm{~kg} \mathrm{~m}^{-3}\right)\left(\mathrm{mm} \mathrm{day}^{-1}\right)^{-0.4}$ & - & - & - & 2.5 \\
\hline & & & \multicolumn{4}{|c|}{ Source limit } \\
\hline & Saturated area $a_{s 1}$ & $\left(\mathrm{~kg} \mathrm{~m}^{-3}\right)\left(\mathrm{mm} \mathrm{day}^{-1}\right)^{-0.4}$ & 0.5 & 0.5 & 0.5 & 0.5 \\
\hline & Degraded area $a_{s 2}$ & $\left(\mathrm{~kg} \mathrm{~m}^{-3}\right)\left(\mathrm{mm} \mathrm{day}^{-1}\right)^{-0.4}$ & 0.5 & 0.5 & 0.5 & 0.5 \\
\hline & Road area $a_{s 4}$ & $\left(\mathrm{~kg} \mathrm{~m}^{-3}\right)\left(\mathrm{mm} \mathrm{day}^{-1}\right)^{-0.4}$ & - & - & 1.6 & 0.5 \\
\hline
\end{tabular}


Table 2. Efficiency measures for the hydrology and sediment transport portion of the model used to simulate the discharge and sediment concentrations in the sub-watershed at Weir 1 and Shanko Bahir representing Weir 2 in Tilahun et al. (2015). The scenarios with road area contributions (w. road) and dynamic erodibility of the road area (w. road d.e.) show improved NSE and lower RMSE. Values for Weir 1 are provided for comparison with Tilahun et al. (2015).

\begin{tabular}{|c|c|c|c|c|c|c|}
\hline Model Component & $\begin{array}{c}\text { Model } \\
\text { evaluation }\end{array}$ & Coefficients & Weir 1 & Weir 2 & $\begin{array}{c}\text { Weir } 2 \mathrm{w} . \\
\text { road }\end{array}$ & $\begin{array}{l}\text { Weir } 2 \text { w. } \\
\text { road d.e. }\end{array}$ \\
\hline \multicolumn{7}{|l|}{ Hydrology } \\
\hline & Calibration & NSE & 0.66 & 0.71 & 0.72 & 0.72 \\
\hline & Validation & NSE & & 0.66 & 0.67 & 0.67 \\
\hline & Calibration & PBIAS (\%) & & 31 & 27 & 27 \\
\hline & Validation & PBIAS (\%) & & -4 & -12 & -12 \\
\hline & Calibration & RMSE & & 2.71 & 2.65 & 2.65 \\
\hline & Validation & RMSE & & 0.89 & 0.88 & 0.88 \\
\hline \multicolumn{7}{|l|}{ Sediment transport } \\
\hline & Calibration & NSE & 0.8 & $0.47^{\mathrm{a}}$ & $0.54^{\mathrm{b}}$ & $0.56^{\mathrm{c}}$ \\
\hline & Validation & NSE & & 0.57 & 0.71 & 0.75 \\
\hline & Calibration & PBIAS (\%) & & 24 & 29 & 28 \\
\hline & Validation & PBIAS (\%) & & -32 & -13 & -16 \\
\hline & Calibration & RMSE & & 2.80 & 2.63 & 2.57 \\
\hline & Validation & RMSE & & 0.81 & 0.67 & 0.63 \\
\hline
\end{tabular}

a NSE when excluding an extreme outlier was 0.58
${ }^{b}$ NSE when excluding an extreme outlier was 0.70
${ }^{c}$ NSE when excluding an extreme outlier was 0.73
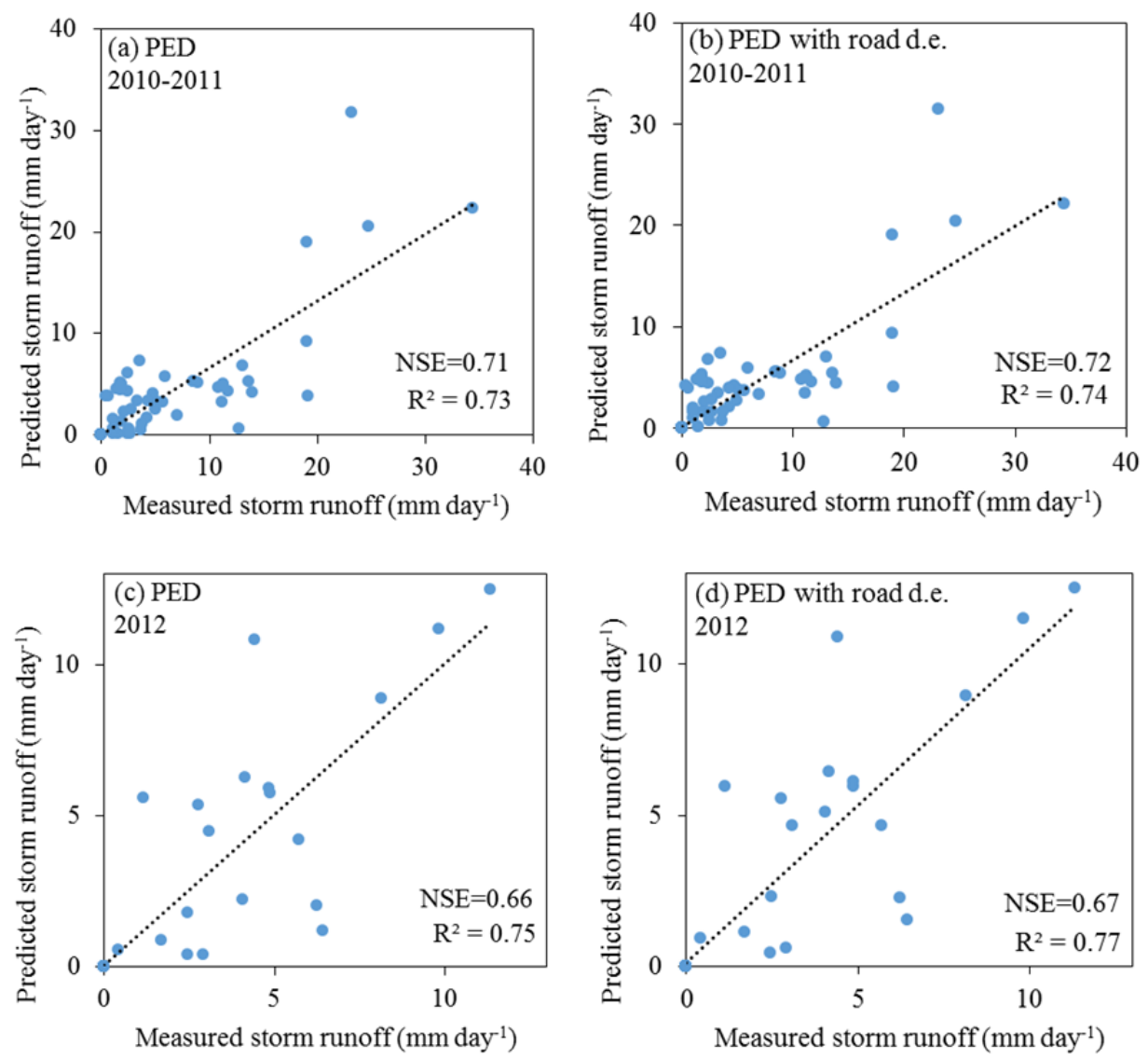

Fig. 5. Scatter plot of the measured $v s$. predicted storm runoff $\left(\mathrm{mm} \mathrm{day}^{-1}\right)$ for calibration years of 2010-2011 for (a) PED original and (b) PED with road and dynamic erodibility (d.e.). Validation of (c) PED original and (d) PED with road and dynamic erodibility (d.e.) occurred for 2012 . 

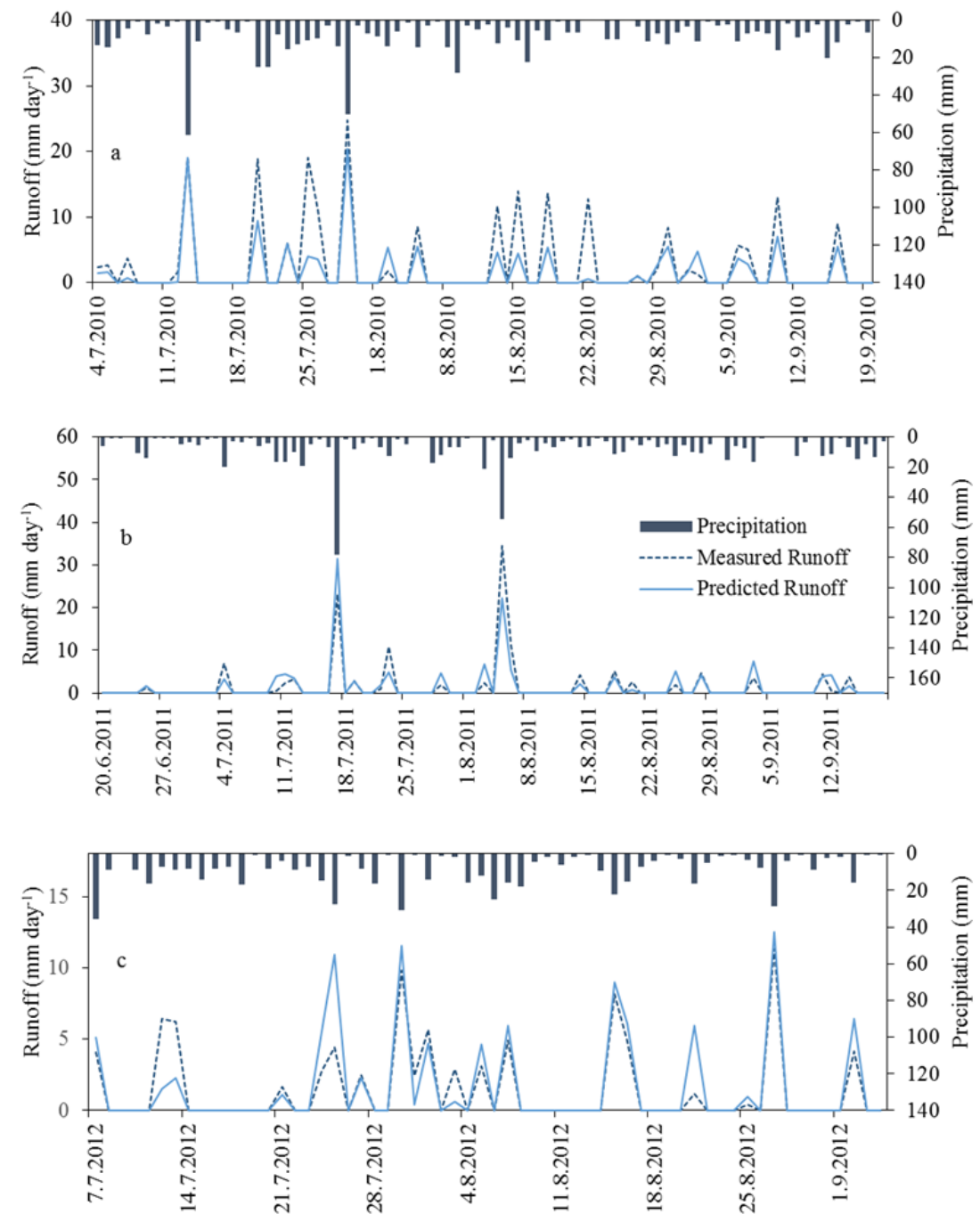

Fig. 6. Measured and predicted storm runoff for (a) 2010, (b) 2011, and (c) 2012.

\section{Discharge simulation}

The values for the $S_{\max }, B S_{\max }$, half-life $\left(t_{1 / 2}\right)$, and interflow parameter $\left(\tau^{*}\right)$ were kept consistent with the parameters calibrated with the surrounding sub-watersheds of the Debre Mawi watershed (Table 1) studied by Tilahun et al. (2015). Shanko Bahir corresponds to the sub-watershed at "Weir 2" in the previous investigation (Tilahun et al., 2015). The hydrological portion of the model implementation differed from Tilahun et al. (2015) in two ways. First, the areal fraction calibrated parameters $\left(A_{1}, A_{2}\right.$, and $\left.A_{3}\right)$ in Shanko Bahir for the saturated, degraded and permeable hillsides differed from the nearby subwatershed (at Weir 1) in Debre Mawi. Secondly, the unpaved road also routed a portion of the runoff to the outlet through its areal fraction $\left(A_{4}\right)$ after exceeding the water storage capacity of this road area $\left(S_{\max 4}\right)$. The total area contributing discharge to the broad-crested weir in Shanko Bahir was similar to the subwatershed at Weir $1(63 \% v s .68 \%)$ however the main difference lies in the composition of the conceptual areas described in the model. They are more evenly distributed in Shanko Bahir than they are in sub-watershed 1 (Table 1) with more fractional saturated areas, $A_{1}\left(0.15 \mathrm{vs}\right.$. 0.08), and less degraded hillside, $A_{2}$ $(0.15 v$ s. 0.20$)$, and less permeable areas $(0.22$ vs. 0.40$)$. The lower portion of this sub-watershed was found to be saturated throughout the rainy season after a couple weeks of rainfall with the exception of a small portion of planted eucalyptus that was less saturated.

The unpaved road represents $11 \%$ of the total sub-watershed area. Combined with the degraded area (15\% of the total area), this would represent $26 \%$ of the area in the watershed. The maximum water storage capacity $\left(S_{\max 4}\right)$ for the road surface was found to be $2 \mathrm{~mm}$. The currently adjusted semi-distributed hydrology component of the model provides reasonable results (Moriasi et al., 2007) with NSE of 0.72, a coefficient of determination $\left(R^{2}\right)$ of 0.74 (Figure 5), PBIAS of $27 \%$, and RMSE of 2.65 (Table 1) for calibration. Without the road contribution, the NSE is 0.71 , the $R^{2}$ is 0.73 , and RMSE is 2.71 . There is some improvement in efficiency, but the hydrology component appears to already be performing well even without the road contribution. The under-predicted values in the first year seem to be evened out by the over-predicted values in the second year (Figure 6), but relatively more effectively simulated in the third year. This is noticeable in the PBIAS being positive (27\%) for the first two years, but lower in magnitude and negative $(-12 \%)$ in the final year (Moriasi et al., 2007). The overpredicting (negative PBIAS) in the last year may have been due to the validation occurring during a drier year than the previous two years when the model was calibrated (Moriasi et al., 2007). For validation, the added road contribution has NSE $=0.67, R^{2}$ $=0.77$, and $\mathrm{RMSE}=0.88$ compared to $\mathrm{NSE}=0.66, R^{2}=0.75$, and $\mathrm{RMSE}=0.89$ without the road contribution. 

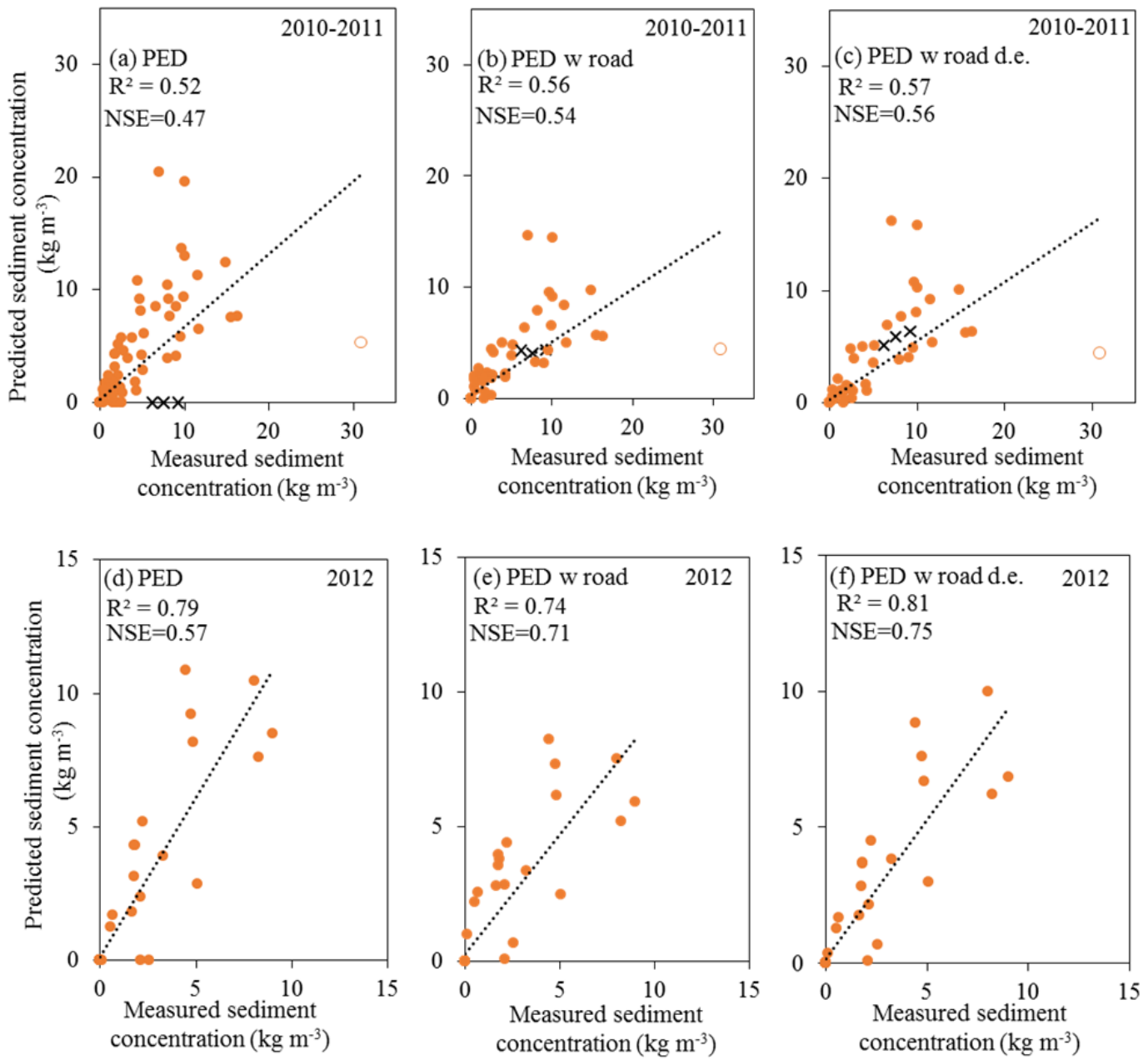

Fig. 7. Scatterplot of measured vs predicted sediment concentrations for Shanko Bahir during calibration (2010-2011) using (a) original PED model without road contributions (b) PED model with road contributions (c) PED model with road contributions and dynamic erodibility. $R^{2}$ for all values shown includes extreme event (open circle) shown on the far right of plots 2010-2011. "x"-marks show three events early in the rain seasons (from left to right June 25, 2011, July 4 and 5,2010) for which the road inclusion improved prediction. Validation during 2012 is shown for (d) original PED model without road contributions (e) PED model with road contributions (f) PED model with road contributions and dynamic erodibility.

\section{Sediment concentration simulation}

The results for concentration predictions illustrate the importance of how this road flow contributes sediment. The source-limiting condition parameters were kept consistent with the small sub-watershed (at Weir 1) nearest to Shanko Bahir (Table 2), while the transport-limiting condition parameter for the degraded area was lowered slightly $\left(a_{t 2}=5\right)$.

The new source-limiting condition parameter for the road surface in the first scenario $\left(a_{s 4}=1.6\right)$ is greater than the parameter representing this condition for degraded areas in the other sub-watershed within Debre Mawi $\left(a_{s}=0.5\right)$, but it is intermediately high compared to the entire Debre Mawi watershed $\left(a_{s}=3\right)$ (Tilahun et al., 2015). For the second scenario where there is dynamic erodibility (d.e.) to describe the temporal variations in road sediment transport (Ziegler et al., $2000)$, the new road source-limiting condition parameter $\left(a_{s 4}\right)$ is 0.5 and the new road transport-limiting condition parameter is closer to $3\left(a_{t 4}=2.5\right)$. The NSE for calibration was 0.54 (with road) and 0.56 (with road, dynamic erodibility), with an $R^{2}$ value of 0.56 (with road) and 0.57 (with road, dynamic erodibility), when including an event on August 2, 2010 (Figure 7). RMSE results were 2.63 (with road) and 2.57 (with road, dy- namic erodibility), and PBIAS results were $29 \%$ (with road) and $28 \%$ (with road, dynamic erodibility). The August 2, 2010 event $\left(30.8 \mathrm{~kg} \mathrm{~m}^{-3}\right.$, Figure $8 \mathrm{a}$, red open circle) was an extreme value caused by a very low discharge value $(1.8 \mathrm{~mm})$ with slightly above average sediment load transport $\left(0.56 \mathrm{t} \mathrm{ha}^{-1}\right)$ for $13.9 \mathrm{~mm}$ of rainfall (Figure 8 ). The next nearest sediment concentration value measured was $16.3 \mathrm{~kg} \mathrm{~m}^{-3}$, occurring on July 12,2011 for $10.2 \mathrm{~mm}$ of rainfall and $3.3 \mathrm{~mm}$ of discharge. A likely scenario could either be related to the progression of gully erosion or an extreme rain event on July 29, 2010 $(50 \mathrm{~mm})$ that could have been transporting sediment over the surface of the watershed but not entirely out to the weir outlet. Either of these circumstances could be resulting in higher than usual sediment concentrations when that particular storm occurred on August 2, 2010. Excluding this event, the performance increases for calibration for the scenario with road contributions, NSE $=0.70$ and $R^{2}=0.71(0.58,0.64$ respectively for the original PED without road contributions). For the scenario with road contributions and dynamic erodibility the calibration improves further, NSE, $R^{2}=0.73$, (Table 2).

The improvement in model efficiency was more important for the sediment concentration estimates than it is for the discharge. The dynamic erodibility improves model efficiency 

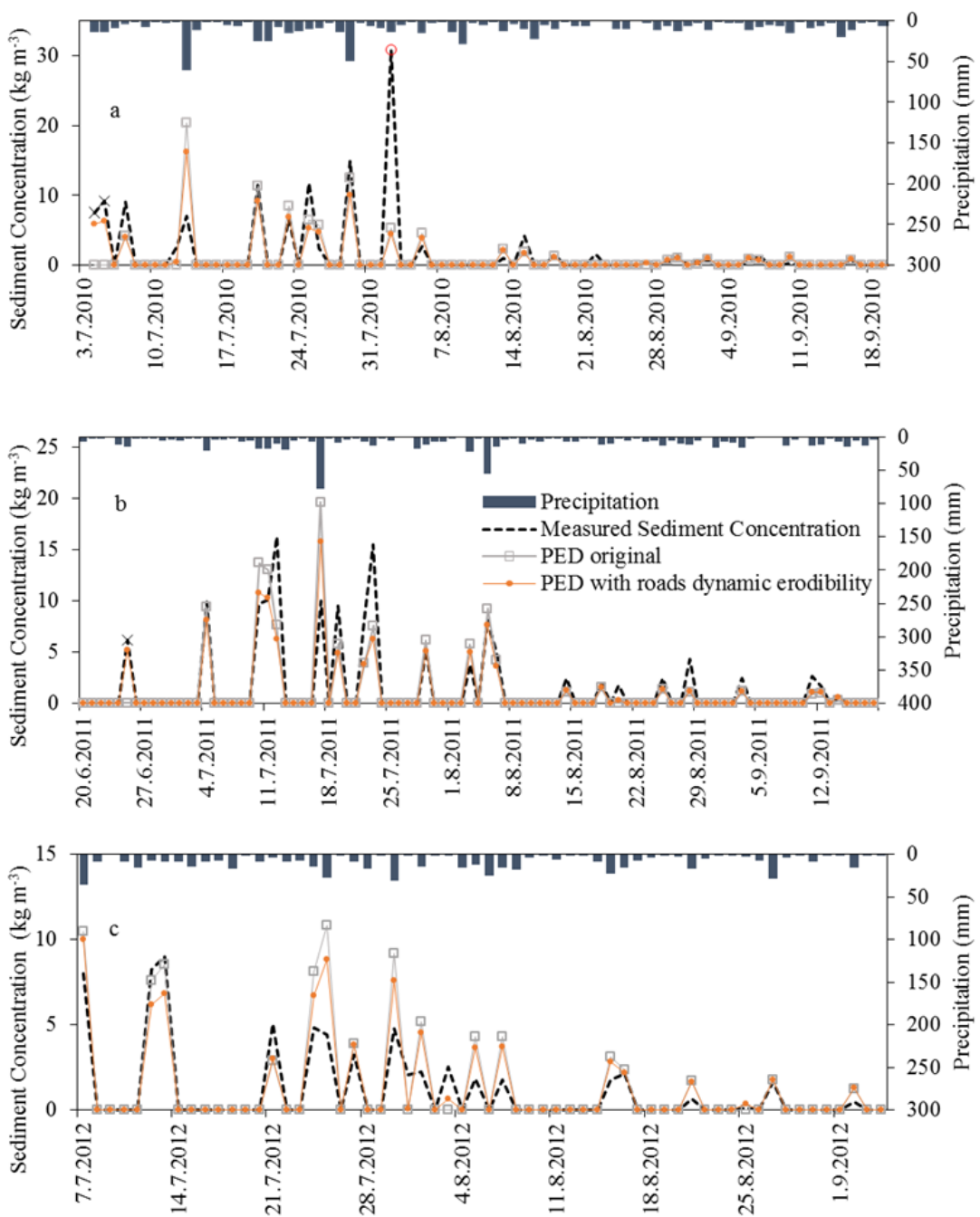

Fig. 8. Measured and predicted sediment concentrations for the Shanko Bahir sub-watershed in the original PED formulation (gray line) and in the modification with unpaved road contributions and dynamic erodibility (orange line) for the years (a) 2010, (b) 2011, and (c) 2012. "x"-marks show three events early in the rain seasons (on July 4 and July 5, 2010 and June 25, 2011) for which the road inclusion improved prediction. Extreme event (open circle) shown in the middle of graph for 2010.

even further than just incorporating a constant road contribution sediment transport parameter. Compared to the performance when the road is included with dynamic erodibility $(\mathrm{NSE}=$ $\left.0.56, R^{2}=0.57\right)$, the results without the road decrease in predictive performance for calibration and validation. Without the modeled contribution from the road the NSE is 0.47 and the $R^{2}$ is 0.52 for calibration. Three events producing sediment at the beginning of the season in particular are important for improvement of these results in this sub-watershed. On July 4 and 5, 2010 and June 25, 2011, sediment concentration values were measured as 7.5, 9.2, and $6.2 \mathrm{~kg} \mathrm{~m}^{-3}$, (Figure 8), however the amount of effective precipitation $\left(P_{e}\right)$ was not enough (around $11 \mathrm{~mm}$ each time) to exceed the storage capacity of the different areas of the watershed this early in the season in order to produce runoff and sediment. Thus, the original formulation without the road contributions did not produce sediment (Figure $7 \mathrm{~b}$, shown by the predicted 0 values), however with the road included as an area with minimal storage more plausible results were obtained with values of: $8.5,8.0$, and $3.4 \mathrm{~kg} \mathrm{~m}^{-3}$, respectively (Figure 8). Likewise an improvement was seen for validation year 2012 as NSE was 0.57 and $R^{2}$ was 0.79 and increased to NSE $=0.75$ and the $R^{2}=0.81$. RMSE and PBIAS reduce in magnitude from 0.81 and $-32 \%$ to 0.63 and $-16 \%$, respectively showing the model more effectively simulates sediment concentrations, though slightly over-predicted, with the road. Similar to the discharge results the model changes from under-predicting (positive PBIAS) to over-predicting with lower deviation (lower and negative PBIAS) possibly reflecting the change from calibrating in wet years to validating in a drier year (Moriasi et al., 2007).

\section{DISCUSSION}

The influence of the unpaved road on this watershed's hydrological and geomorphological processes and trends are evident from direct observation and through improved prediction efficiencies. Having a model for understanding these changes is not enough and it is very important to consider how the model is applied and what it includes. Similar trends of increasing stream discharge with decreasing sediment transport are found throughout Ethiopia (Easton et al., 2010; Guzman et al., 2013; Tilahun et al., 2013; Vanmaercke et al., 2010) and in other sub-humid highland catchments (Steenhuis et al., 2013). Yet, the exact mechanisms and sediment sources are being 
scrutinized more recently in the Amhara sub-humid region (Bayabil et al., 2010; Setegn et al., 2010; Tebebu et al., 2010, 2015). Comparisons with the drier Tigray region (Nyssen et al., 2006; Vanmaercke et al., 2010; Walraevens et al., 2009; Zenebe et al., 2013) are helping to better understand and evaluate the performance of soil and water conservation measures. The quick generation and increased runoff and sediment in Shanko Bahir relative to the nearby sub-watershed were observable during field work and complicated previous modeling efforts (Tilahun et al., 2015). Incorporating unpaved road surfaces into this model, however, demonstrates the applicability of this model to other watersheds inside and outside of Ethiopia. The results show that saturation-excess should be used as the dominant runoff mechanism in climates such as these highland areas and that such a model can realistically integrate infiltrationexcess mechanism components, though the unpaved road is the sole consideration for Hortonian flow presented in this study.

\section{Influence of the road on hydrology and sediment transport}

An increase in degraded or compacted lands can influence runoff and sediment production. While the degraded area can result from land transformations related to rural agriculture, the increased presence of roads in the countryside reflects an ongoing urbanization occurring as countries such as Ethiopia aim for greater economic development. Two trends in the results are useful for the assessment of the repercussions of developing road networks. First, the hydrology was minimally impacted in an overall sense, however, there seems to be more marked influence of the hydrological impact during rain events occurring early in the season. Second, sediment transport appears to increase.

The hydrological pattern changes are not as drastically changed by the presence of this unpaved road as expected when assessing urbanization repercussions. The road's influence is minimal on the model efficiency, which possibly is related to the extent of surface cover change and the location at which it occurs. The pressures expected by replacing natural landscapes with impermeable surfaces are decreased capacity to infiltrate precipitation, increased runoff production, and decreased recharge of water tables (Schuster et al., 2005). As currently included, the unpaved road's influence should have these effects, however, presently the $11 \%$ of proportional area the road makes up seems not to create such directly apparent trends. This could be evidence showing that the width of this road (roughly $10 \mathrm{~m}$ ) does not lead to direct negative consequences for the hydrology cycle in a small watershed area (much less a larger watershed). However, this unpaved road falls into a special case requiring some attention due to the dynamic level of perviousness (Schuster et al., 2005).

The unpaved surface has similarities with exposed bedrock (flow over it may infiltrate further down slope) meaning it may in some ways be a "degraded area" in the original model approach. Yet, improved sediment concentration simulation shows the current inclusion of unpaved surfaces is more accurately representing the hydrologic processes. The maximum water storage capacity $\left(S_{\max 4}\right)$ for the road area was found to be $2 \mathrm{~mm}$ by calibration which is much lower than the saturated and permeable hillside areas and one-fifteenth the degraded area maximum water storage capacity. The nearest similar value of $10 \mathrm{~mm}$ for $S_{\max }$ for degraded areas is found in a study of watersheds in the Blue Nile Basin (Tilahun et al. 2013a). The value of $2 \mathrm{~mm}$, hence, is sufficiently small and practical for representation of an unpaved surface. The road does, however, have depression storage due to the roadside ditches that eventu- ally guide the flow from the northernmost parts of Shanko Bahir down to the outlet weir (Figure 2a). Though it may not greatly increase model efficiency, it is improving our understanding of the effect of the road. Rainfall that might have infiltrated in the upper parts of the watershed is instead leading to quicker generation of overland flow or saturation in nearby areas. Roadside ditches can also intercept surface and shallow subsurface flow routing them on a more direct path to the outlet (Montgomery, 1994; Ziegler and Giambelluca, 1997). This was seen in a few instances in the graphs as peaks are reached faster than in the original approach.

The sediment transport capacity parameter $\left(a_{t 2}\right)$ for the degraded areas was slightly lower than the nearby sub-watershed. Although Shanko Bahir had a greater portion of land in cultivation, possibly leading to either higher or equal transport limiting conditions for sediment transport, some of these cultivated areas were treated with soil conservation bunds potentially influencing these sediment source conditions. Moreover, some of this sub-watershed is divided from the rest by the road which could further alter the connectivity of high transport conditions. The increased modeling efficiency gained from capturing this quicker generation of runoff demonstrates the more directly visible impact of including this new component. Furthermore, the road surface as an additional source of sediment is reasonable since it constitutes a source of fine material that is renewed annually and through detachment by vehicle usage, rainfall impact, livestock usage, and other biological activity (Burroughs et al., 1984).

\section{Contributing runoff mechanisms and roads in the sub- humid Ethiopian highlands}

Saturation-excess overland flow in the sub-humid Ethiopian highlands has been argued to be the dominant runoff generation mechanism based on data analysis, field experiments, and observations (Bayabil et al., 2010; Liu et al, 2008; Tebebu et al., 2010; Tilahun et al., 2013a, b, 2015). Other researchers have also noted the importance of soil moisture storage and saturation for runoff generated in highland watersheds (Bewket and Sterk, 2003; Zeleke, 2001). However, there are instances in which the infiltration capacity is exceeded by very intense rainstorms, leading to Hortonian overland flow. In the semi-arid highlands of Ethiopia, studies have also shown the presence of saturation-excess as a mechanism, however, only during certain parts of the rainy season. In Tigray, infiltration-excess overland flow caused by heavy or high intensity storms has been shown to be common early in the rainy season (Descheemaeker et al., 2009; Walraevens et al., 2009; Zenebe et al., 2013). Thus, although these regimes occur with varying intensity in different watersheds, few attempts had been made to integrate both mechanisms in a satisfactory way. Dunne (1983) argued that the value of a theoretical model is greatly enhanced when developed in close cooperation with field studies. The PED model was developed so that it would provide an adequate description of field conditions acknowledging the dominance of one mechanism (saturation-excess) over the other (infiltration-excess).

There are few studies within the sub-humid Ethiopia highlands focused on daily sediment transport modeling from roads and farm tracks. Haregeweyn et al. (2013) explicitly mention inclusion of roads through parcel data increasing their accuracy of the hydrological processes, however few implications are mentioned. Nyssen et al. (2002) investigated the increasing prevalence of gullies after a road was constructed in the semiarid Tigray region, however, surface runoff data was not available. The measured increase of catchment area for identified 
gullies was linked directly to the increased gully erosion in the study site due to higher runoff volumes, larger peak flows, and shorter concentration times. The road drainage ditches in the Shanko Bahir watershed similarly disperses runoff into higher discharge volumes with shorter concentration times to its final downslope outlet where a gully is located and actively eroding (Figure 1). Teweldebrihan (2014) modeled intensified runoff from paved roads in Tigray using the HBV model. In other mountainous areas, Ziegler and Giambelluca (1997) emphasized the importance of rural roads as source areas for runoff in northern Thailand and hypothesized that roads contribute to basin hydrographs disproportionately to their areal extents (less than 5\%). In a later study, Ziegler et al. (2001) demonstrate how footpaths $(8-24 \%$ of field surface areas) drastically increase runoff coefficients (50\% higher) and Hortonian overland flow and how they decrease the time to generate runoff in northern Thailand. Harden (1992) is one of the few studies that shows how rural roads and footpaths in highland Ecuador and East Tennessee impact runoff and erosion modeling and their inclusion in modeling inhabited mountainous landscapes is strongly argued since they are the most active runoff-generating components. In this analysis, the road was found to make up $11 \%$ of the fractional area of the sub-watershed and accounted for more of the variability in the measured vs predicted sediment concentrations.

\section{Limitations of the model}

The large and rare events that are caused either by gully wall collapse or remobilization of sediment present a limitation to this model. In the Shanko Bahir sub-watershed, previous attempts to predict the discharge and sediment concentrations with similar parameters as nearby sub-watersheds did not perform well (Tilahun et al., 2015) and had to be modified before the model could provide reasonable results. Still, the presence of gullies in this small sub-watershed and the nearby subwatersheds continues to provide challenges to adequately describing the field conditions. Advancing head cuts and slumps in these channels can lead to very high sediment transport events. The incorporation of the flow from the road, however, at least shows that with only three to four more parameters $\left(A_{4}\right.$, $\left.S_{\max 4}, a_{s 4}, a_{t 4}\right)$, the PED model can remain a simple semidistributed model that can predict the hydrology and sediment concentrations in a data-scarce environment on a daily basis. Future developments on the model will aim to fully describe similar low permeability surfaces such as foot paths, address the connectivity of sediment transport along the hillslope, and incorporate threshold limits for moisture and gully expansion events.

The extra parameters introduced into the model explicitly taking into account the road improve the model representation of the natural processes. The model performance with the road, however, only improves slightly in the hydrology portion of the model.

\section{CONCLUSION}

Research on soil erosion processes in Ethiopia has been increasing as access to field data and computing capability have increased. Local and international research institutions within different parts of Ethiopia are increasingly involved in projects attempting to understand the complex physical components of the food security challenge through comprehensive data collection and contextualized data analysis. This model's development has benefited from these two trends especially in the data-scarce regions of East Africa. The PED model, while benefitting from computing capabilities, is most influenced by field data showing greater soil infiltration capacities than rainfall intensities in sub-humid Ethiopian highland watersheds. For most Ethiopian watersheds modeled so far the PED model performed reasonably well, however, the Shanko Bahir subwatershed provided difficulty in using strictly the saturationexcess runoff mechanism due to the presence of an unpaved road contributing overland flow and especially sediment as the findings show. The modifications made in this study to accommodate the overland flow and sediment contributions from this road with low hydraulic conductivity resulted in similar validation NSE and $R^{2}$ values for previous studies on a daily basis in the Debre Mawi watershed and also in other Blue Nile Basin watersheds (NSE $=0.67, R^{2}=0.77$ for discharge and NSE $=$ $0.75, R^{2}=0.81$ for sediment concentrations). The sediment portion of the analysis provided the most improvement showing that incorporating sediment sources such as roads or other areas with low hydraulic conductivity is an important step to improving erosion modeling efforts. The data furthermore show that increased variability in discharge and sediment concentrations in this sub-watershed can be attributed to the unpaved road and that soil and water conservation structures need to recognize these added contributions if sediment concentrations in streams are to be reduced.

Acknowledgements. I would like to thank the Amhara Regional Agricultural Research Institute and Bahir Dar University for all their assistance in facilitating data collection and analysis. Whole-hearted appreciation goes to the community assistants who collected the field data. Funding for this project was made possible through the Cornell International Institute for Food, Agriculture and Development NSF IGERT on Food Systems and Poverty Reduction, Cornell Graduate School Travel Grant, the U.S. Borlaug Fellows in Global Food Security Program, and the NSF Graduate Research Fellowship Program. Additional assistance was possible through the USAID Partnerships for Enhanced Engagement in Research (PEER) Science project (grant number AID-OAA-A-11-00012).

\section{REFERENCES}

Abiy, A.Z., 2009. Geological Controls in the Formations and Expansions of Gullies over Hillslope Hydrological Processes in the Highlands of Ethiopia, Northern Blue Nile Region. Cornell University, Ithaca.

Anderson, D.M., MacDonald, L.H., 1998. Modelling road surface sediment production using a vector geographic information system. Earth Surf. Process. Landf., 23, 95-107.

Arnold, J.G., Srinivasan, R., Muttiah, R.S., Williams, J.R., 1998. Large area hydrologic modeling and assessment part I: Model development. J. Amer. Water Resour. Assoc., 34, 7389.

Bayabil, H.K., Tilahun, S.A., Collick, A.S., Yitaferu, B., Steenhuis, T.S., 2010. Are runoff processes ecologically or topographically driven in the (sub) humid Ethiopian highlands? The case of the Maybar watershed. Ecohydrology, 3, 457466. DOI: $10.1002 /$ eco. 170.

Beven, K.J., Kirkby, M.J., 1979. A physically based, variable contributing area model of basin hydrology. Hydrol. Sci. Bull., 24, 43-69.

Bewket, W., Sterk, G., 2003. Assessment of soil erosion in cultivated fields using a survey methodology for rills in the Chemoga watershed, Ethiopia. Agric. Ecosyst. Environ., 97, 81-93. DOI: 10.1016/S0167-8809(03)00127-0. 
Burt, T.P., McDonnell, J.J., 2015. Whither field hydrology? The need for discovery science and outrageous hydrological hypotheses. Water Resour Res., 51, 5919-5928, DOI: 10.1002/2014WR016839.

Buytaert, W., De Bièvre, B., Wyseure, G., Deckers, J., 2004. The use of the linear reservoir concept to quantify the impact of changes in land use on the hydrology of catchments in the Andes. Hydrol. Earth Sys. Sci., 8, 108-114.

Betrie, G.D., Mohamed, Y.A., van Griensven, A., Srinivasan, R., 2011. Sediment management modelling in the Blue Nile Basin using SWAT model. Hydrol. Earth Syst. Sci., 15, 807-818. DOI: 10.5194/hess-15-807-2011.

Bingner, R.L., Theurer, F.D., 2007. Research: AGNPS. US Department of Agriculture-Agriculture Research Service. [Online]. Available: <http://www.ars.usda.gov/Research/ docs.htm?docid=5199>. Accessed 9 December 2014.

Burroughs, E.R., Jr., Watts, F.J., Haber, D.F., 1984. Surfacing to reduce erosion of forest roads built in granitic soils. In: C.L. O'Loughlin, A.J. Pierce (Eds.): Proc. of a Symposium on Effects of Forest Land Use on Erosion and Slope Stability, 7-11 May 1984, University of Hawai'i, East-West Center, Honolulu, HI, pp. 255-264.

Caballero, L.A., Easton, Z.M., Richards, B.K., Steenhuis, T.S., 2013. Evaluating the bio-hydrological impact of a cloud forest in Central America using a semi-distributed water balance model. J. Hydrol. Hydromech., 61, 9-20.

Ciesiolka, C.A., Coughlan, K.J., Rose, C.W., Escalante, M.C., Hashim, G.M., Paningbatan, E.P., Sombatpanit, S., 1995. Methodology for a multi-country study of soil erosion management. Soil Technol., 8, 179-192. DOI: 10.1016/09333630(95)00018-6.

Collick, A.S., Easton, Z.M., Ashagrie, T., Biruk, B., Tilahun, S., Adgo, E., Awulachew, S.B., Zeleke, G., Steenhuis, T.S., 2009. A simple semi-distributed water balance model for the Ethiopian highlands. Hydrol. Process., 23, 3718-3727.

Descheemaeker, K., Raes, D., Nyssen J., Poesen, J., Haile, M., Deckers, J., 2009. Changes in water flows and water productivity upon vegetation regeneration on degraded hillslopes in northern Ethiopia: a water balance modelling exercise. Rangeland J., 31, 237-249. http://dx.doi.org/10.1071/RJ09010.

Dooge, J.C.I., 1986. Looking for hydrological laws. Water Resour. Res., 22, 9, 46S-58S.

Dunne, T., 1978. Field studies of hillslope flow processes. In: Kirkby,M.J. (Ed.): Hillslope Hydrology, John Wiley, New York, pp. 227-293.

Dunne, T., 1983. Relation of field studies and modeling in the prediction of storm runoff. J. Hydrol., 65, 25-48.

Dunne, T., Black, R.D., 1970. Partial area contributions to storm runoff in a small New England watershed. Water Resour. Res., 6, 1296-1311.

Dunne, T., Dietrich, W., 1982. Sediment sources in tropical drainage basins. In: Kussow, W. (Ed.): Soil Erosion and Conservation in the Tropics. American Society of Agronomy, Madison, pp. 41-53.

Easton, Z.M., Fuka, D.R., White, E.D., Collick, A.S., Biruk Ashagre, B., McCartney, M., Awulachew, S.B., Ahmed, A. A., Steenhuis, T.S., 2010. A multi basin SWAT model analysis of runoff and sedimentation in the Blue Nile, Ethiopia. Hydrol. Earth Syst. Sci., 14, 1827-1841, DOI: 10.5194/hess14-1827-2010.

Guzman, C.D., Tilahun, S.A., Zegeye, A.D., Steenhuis, T.S., 2013. Suspended sediment concentration-discharge relationships in the (sub-) humid Ethiopian highlands. Hydrol. Earth Syst. Sci., 17, 1067-1077. DOI: 10.5194/hess-17-1067-2013.
Hairsine, P.B., Rose, C.W., 1992. Modeling water erosion due to overland flow using physical principles 1 . Sheet flow. Water Resour. Res., 28, 237-243.

Haith, D., Shoemaker, L.L., 1987. Generalized Watershed Loading Functions for stream flow nutrients, J. Am. Water Resour. As., 23, 471-478. DOI: 10.1111/j.17521688.1987.tb00825.x.

Harden, C.P., 1992. Incorporating roads and footpaths in watershed-scale hydrologic and soil erosion models. Physical Geography, 13, 368-385.

Haregeweyn, N., Poesen, J., Verstraeten, G., Govers, G., de Vente, J., Nyssen, J., Deckers, J., Moeyersons, J., 2013. Assessing the performance of a spatially distributed soil erosion and sediment delivery model (WATEM/SEDEM) in Northern Ethiopia. Land Degrad. Dev., 24, 188-204.

Hengsdijk, H., Meijerink, G., Mosugu, M., 2005. Modelling the effect of three soil and water conservation practices in Tigray, Ethiopia. Agric. Ecosyst. Environ., 105, 29-40.

Hewlett, J.D., Hibbert, A.R., 1967. Factors affecting the response of small watersheds to precipitation in humid areas. In: Sopper, W.E., Lull, H.W. (Eds.): Proc. Int. Symposium on Forest Hydrology. Pergamon, Oxford, pp. 275-290.

Hurni, H., 1998. Agroecological Belts of Ethiopia: Explanatory notes on three maps at a scale of 1:100,000,000. Soil Conservation Research Programme Research report. Centre for Development and Environment, University of Bern, Switzerland.

ISRIC, 2014. International Soil Reference and Information Center. World Soil Information. Last access 22 Nov 2014. $<$ www.isric.org $>$.

Kirkby, M.J., Chorley, R.J., 1967. Throughflow, overland flow and erosion. Int. Assoc. Sci. Hydrol. Bull., 12, 5-21.

Krysanova, V., Müller-Wohlfeil, D.-I., Becker, A., 1998. Development and test of a spatially distributed hydrological/water quality model for mesoscale watersheds. Ecol. Model., 106, 263-289.

Legates, D.R., Mahmood, R., Levia, D.F., DeLiberty, T.L., Quiring, S.M., Houser, C., Nelson, F.F., 2011. Soil moisture: A central and unifying them in physical geography. Prog. Phys. Geog., 35, 65-86.

Liu, B.M., Collick, A.S., Zeleke, G., Adgo, E., Easton, Z.M., Steenhuis, T.S., 2008. Rainfall-discharge relationships for a monsoonal climate in the Ethiopian highlands. Hydrol. Process., 22, 1059-1067. DOI:10.1002/hyp.7022.

McDonnell, J.J., Sivapalan, M., Vache, K., Dunn, S., Grant, G., Haggerty, R., Hinz, C., Hooper, R., Kirchner, J., Roderick, M.L., Selker, J., Weiler, M., 2007. Moving beyond heterogeneity and process complexity: A new vision for watershed hydrology. Water Resour. Res., 43, W07301. DOI: 10.1029/2006WR005467.

Mekonnen, M., Melesse, A.M., 2011. Soil erosion mapping and hotspot area identification using GIS and remote sensing in northwest Ethiopian highlands, near Lake Tana, In: Melesse, A. (Ed.): Nile River Basin: Hydrology, Climate, and Water Use. Chapter 10. Springer Science Publisher, pp. 207-224, DOI: 10.1007/978-94-007-0689-7 10.

Mekonen, M.A., Wörman, A., Dargahi, B., Gebeyehu, A., 2009. Hydrological modelling of Ethiopian catchments using limited data. Hydrol. Process., 23, 3401-3408.

Mohammed, H., Yohannes, F., Zeleke, G., 2004. Validation of agricultural non-point source (AGNPS) pollution model in Kori watershed, South Wollo, Ethiopia. Int. J. Appl. Earth Obs., 6, 97-109. DOI: 10.1016/j.jag.2004.08.002. 
Montgomery, D.R., 1994. Road surface drainage, channel initiation, and slope instability. Water Resour. Res., 30, 19251932.

Moriasi, D.N., Arnold, J.G., Van Liew, M.W., Bingner, R.L., Harmel, R.D., Vieth, T.L., 2007. Model evaluation guidelines for systematic quantification of accuracy in watershed simulations. T. A.S.A.B.E., 50, 885-900.

Nash, J., Sutcliffe, J., 1970. River flow forecasting through conceptual models part I-A discussion of principles. J. Hydrol., 10, 282-290.

Nyssen, J., Poesen, J., Moeyersons, J., Luyten, E., Veyret-Picot, M., Deckers, J., Haile, M., Govers, G. 2002. Impact of road building on gully erosion risk: a case study from the Northern Ethiopian Highlands. Earth Surface Processes and Landforms, 27, 1267-1283.

Nyssen, J., Haregeweyn, N., Descheemaeker, K., Gebremichael, D., Vancampenhout, K., Poesen, J., Haile, M., Moeyersons, J., Buytaert, W., Naudts, J., Deckers, J., Govers, G., 2006. Comment on "Modelling the effect of soil and water conservation practices in Ethiopia" [Agric Ecosyst. Environ. 105 29-40] Agric. Ecosyst. Environ., 114, 407-411.

Rhoads, B.L., 1995. Stream power: a unifying theme for urban fluvial geomorphology. In: Herricks, E.E. (Ed.): Stormwater Runoff and Receiving Systems Impact, Monitoring, and Assessment. CRC Press, Boca Raton, FL, pp. 65-75.

Savenije, H.H.G., 2010. HESS Opinions "Topography driven conceptual modelling (FLEX-Topo)". Hydrol. Earth Syst. Sci., 14, 2681-2692. DOI: 10.5194/hess-14-2681-2010.

Schuster, W.D., Bonta, J., Thurston, H., Warnemuende, E., Smith, D.R., 2005. Impacts of impervious surface on watershed hydrology: A review. Urban Water J., 2, 263-275.

SCS, 1956. National Engineering Handbook, Section 4: Hydrology. Soil Conservation Service, USDA, Washington, D.C., 1956.

Setegn, S.G., Dargahi, B., Srinivasan, R., Melesse, A.M., 2010. Modeling of sediment yield from Anjeni-Gauged Watershed, Ethiopia using SWAT Model. J. Am. Water Resour. As., 46, 3, 514-526. DOI: 10.1111/j.1752-1688.2010.00431.x.

Steenhuis, T.S., Van der Molen, W.H., 1986. The Thornthwaite-Mather procedure as a simple engineering method to predict recharge. J. Hydrol., 84, 221-229.

Steenhuis, T.S. Collick, A.S., Easton, Z.M., Leggesse, E.S., Bayabil, H.K., White, E.D., Awulachew, S.B., Adgo, E., Ahmed, A.A., 2009. Predicting discharge and sediment for the Abay (Blue Nile) with a simple model. Hydrol. Process., 23, 3728-3737. DOI: 10.1002/hyp.7513.

Steenhuis, T.S., Hrncir, M., Poteau, D., Romero Luna, E.J., Tilahun, S.A., Caballero, L.A., Guzman, C.D., Stoof, C.R., Sanda, M., Yitaferu, B., Cislerova, M., 2013. A saturated excess runoff pedotransfer function for vegetated watersheds. Vadose Zone J., 12. DOI: 10.2136/vzj2013.03.0060.

Tebebu, T.Y., Abiy, A.Z., Zegeye, A.D., Dahlke, H.E., Easton, Z.M., Tilahun, S., Collick, A.S., Kidanu, S., Moges, S., Dadgari, F., Steenhuis, T.S., 2010. Surface and subsurface flow effect on permanent gully formation and upland erosion near Lake Tana in the northern highlands of Ethiopia. Hydrol. Earth Syst. Sci., 14, 2207-2217. DOI: 10.5194/hess14-2207-2010.

Tebebu, T.Y., Steenhuis, T.S., Dagnew, D.C., Guzman, C.D., Bayabil, H.K., Zegeye, A.D., Collick, A.S., Langan, S., McAllister, C., Langendoen, E.J., Yitaferu, B., Tilahun, S.A., 2015. Improving efficacy of landscape interventions in the (sub) humid Ethiopian highlands by improved under- standing of runoff processes. Front. Earth Sci., 3. DOI: 10.3389/feart.2015.00049.

Teshome, A., Rolker, D., De Graaff, J., 2013. Financial viability of soil and water conservation technologies in northwestern Ethiopian highlands. Appl Geogr., 37, 139-149.

Teweldebrihan, M.D., 2014. Optimizing intensified runoff from roads for supplemental irrigation: Tigray Region, Ethiopia. M.S. Thesis. UNESCO-IHE, Institute for Water Education, Delft, the Netherlands

Thornthwaite, C.W., Mather, J.R., 1955. The water balance. Publ. Climatol., 8.

Tibebe, D., Bewket, W., 2011. Surface runoff and soil erosion estimation using the SWAT model in the Keleta Watershed, Ethiopia. Land Degrad. Dev., 22, 551-564. DOI: 10.1002/ldr.1034.

Tilahun, S.A., Guzman C.D., Zegeye, A.D., Engda, T.A., Collick, A.S., Rimmer, Steenhuis, T.S., 2013a. An efficient semi-distributed hillslope erosion model for the sub-humid Ethiopian Highlands. Hydrol. Earth Syst. Sci., 17, 10511063. DOI: 10.5194/hess-17-1051-2013.

Tilahun, S.A., Mukundan, R., Demisse, B.A., Engda, T.A., Guzman, C.D., Tarakegn, B.C., Easton, Z.M, Collick, A.S., Zegeye, A.D., Schneiderman, E.M., Parlange, J-.Y., Steenhuis, T.S., 2013b. A Saturation Excess Erosion Model. T. A.S.A.B.E., 56, 681-695. DOI: 10.13031/2013.42675.

Tilahun, S.A., Guzman, C.D., Zegeye, A.D., Steenhuis, T.S., 2015. Distributed discharge and sediment concentration predictions in the sub-humid Ethiopian Highlands: the Debre Mawi Watershed. Hydrol. Process., 29, 1817-1828. DOI: 10.1002/hyp. 10298 .

Tilahun, S.A., Ayana, E.K., Guzman, C.D., Dagnew, D.C., Zegeye, A.Z., Tebebu, T.Y., Yitaferu, B., Steenhuis, T.S., 2016. Revisiting storm runoff processes in the Upper Blue Nile Basin: The Debre Mawi Watershed. Catena, 143, 4756.

Van Griensven, A., Ndomba, P., Yalew, S., Kilonzo, F., 2012. Critical review of SWAT applications in the upper Nile basin countries. Hydrol. Earth Syst. Sci., 16, 3371-3381. DOI: 10.5194/hess-16-3371-2012.

Vanmaercke, M., Zenebe, A., Poesen, J., Nyssen, J., Verstraeten, G., Deckers, J., 2010. Sediment dynamics and the role of flashfloods in sediment export from mediumsized catchments: a case study from the semi-arid tropical highlands in northern Ethiopia. J. Soil Sediments, 10, 611627.

Walraevens, K., Vandecasteele, I., Martens, K., Nyssen, J., Moeyersons, J., Gebreyohannes, T., Smedt, F., Poesen, J., Deckers, J., Van Camp, M., 2009. Groundwater recharge and flow in a small mountain catchment in northern Ethiopia. Hydrol. Sci. J., 54, 739-753. DOI: 10.1623/hysj.54.4.739.

Williams, J.R., Jones, C.A., Dyke, P.T., 1984. A modeling approach to determining the relationship between erosion and soil productivity. Trans. A.S.A.E., 27, 129-144.

White, E.D., Easton, Z.M., Fuka, D.R., Collick, A.S., Adgo, E., McCartney, M., Awulachew, S.B., Selassie, Y.G., Steenhuis, T.S., 2011. Development and application of a physically based landscape water balance in the SWAT model. Hydrol. Process., 25, 915-925. DOI: 10.1002/hyp.7876.

Yesuf, H.M., Assen, M., Alamirew, T., Melesse, A.M., 2015. Modeling of sediment yield in Maybar gauged watershed using SWAT, northeast Ethiopia. Catena, 127, 191-205.

Yu, B., Rose, C.W., Ciesiolka, C.A.A., Coughlan, K.J., Fentie, B., 1997. Toward a framework for runoff and soil loss 
prediction using GUEST technology. Aust. J. Soil Res., 35, 1191-212.

Zeleke, G., 2011. Application and adaptation of WEPP to the traditional farming system of the Ethiopian highlands. Paper presented at the Conference of the International Soil Conservation Organization, Lafayette, 24-28 May 1999.

Zenebe, A., Vanmaercke, M., Poesen, J., Verstraeten, G., Haregeweyn, N., Haile, M., Amare, K., Deckers, J., Nyssen, J., 2013. Spatial and temporal variability of river flows in the degraded semi-arid tropical mountains of northern Ethiopia. Z. Geomorphol., 57, 143-169.

Ziegler, A.D., Giambelluca, T.W., 1997. Importance of rural roads as source areas for runoff in mountainous areas of northern Thailand. J. Hydrol., 196, 204-229.
Ziegler, A.D., Sutherland, R.A., Giambelluca, T.W., 2000. Partitioning total erosion on unpaved roads into splash and hydraulic components: The roles of interstorm surface preparation and dynamic erodibility. Water Resour. Res., 36, 2787-2791.

Ziegler, A.D., Sutherland, R.A., Giambelluca, T.W., 2001. Acceleration of Horton overland flow and erosion by footpaths in an upland agricultural watershed in northern Thailand. Geomorphol., 41, 249-262.

Received 16 May 2016 Accepted 12 July 2016

Note: Colour version of Figures can be found in the web version of this article.

\section{SUPPLEMENTARY MATERIAL}

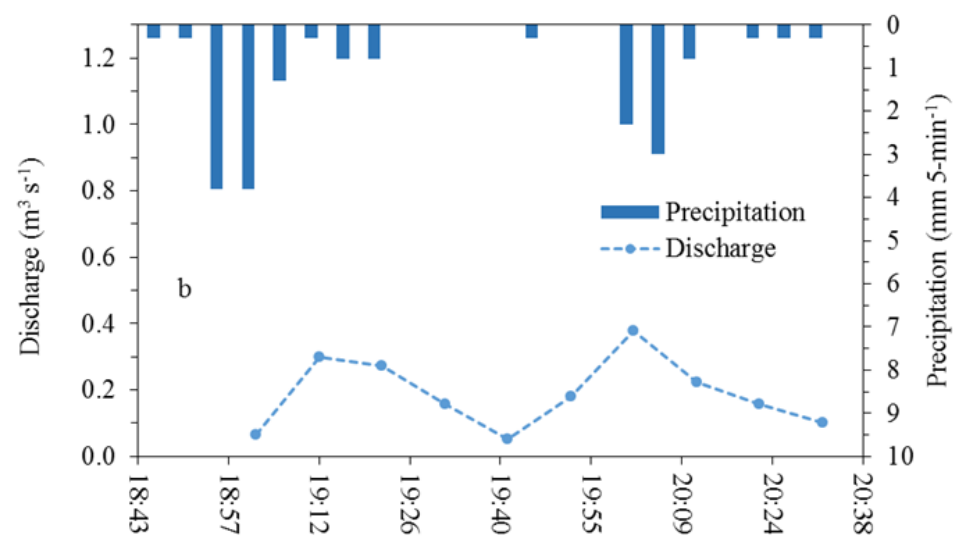

Time

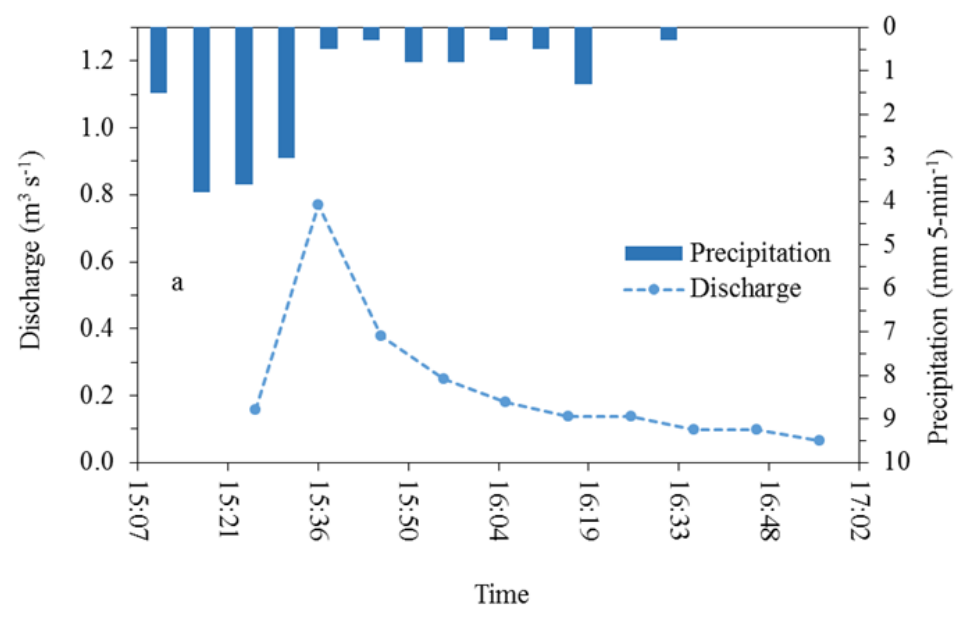

Fig. S1. Discharge dynamics for an event on (a) July 30, 2012 and (b) August 15, 2012 for which discharge $\left(\mathrm{m}^{3} \mathrm{~s}^{-1}\right)$ is plotted on the primary y-axis in 10-min intervals against time and precipitation $(\mathrm{mm})$ is plotted in 5-min intervals on the secondary y-axis. The first graph presented (a) shows a rapid rise in streamflow after a short delay followed by a slow recession and the second graph (b) shows a similar short delay in response to rainfall followed by a recession, but then an additional rainstorm which has a coinciding streamflow peak. 